Expanding the phytoalexin chemical space: Tropalexins A and B from Tropaeolum majus suggest evolutionary conservation of biosynthetic enzymes

\author{
M. Soledade C. Pedras* and Mahla Alavi \\ Department of Chemistry, University of Saskatchewan, 110 Science Place, \\ Saskatoon SK S7N 5C9, Canada
}

*Corresponding author: M. Soledade C. Pedras; e-mail: s.pedras@usask.ca

ORCID iD https://orcid.org/0000-0002-9510-2215 


\section{Expanding the phytoalexin chemical space: Tropalexins A and B from Tropaeolum majus suggest evolutionary conservation of biosynthetic enzymes}

\section{Graphical abstract}

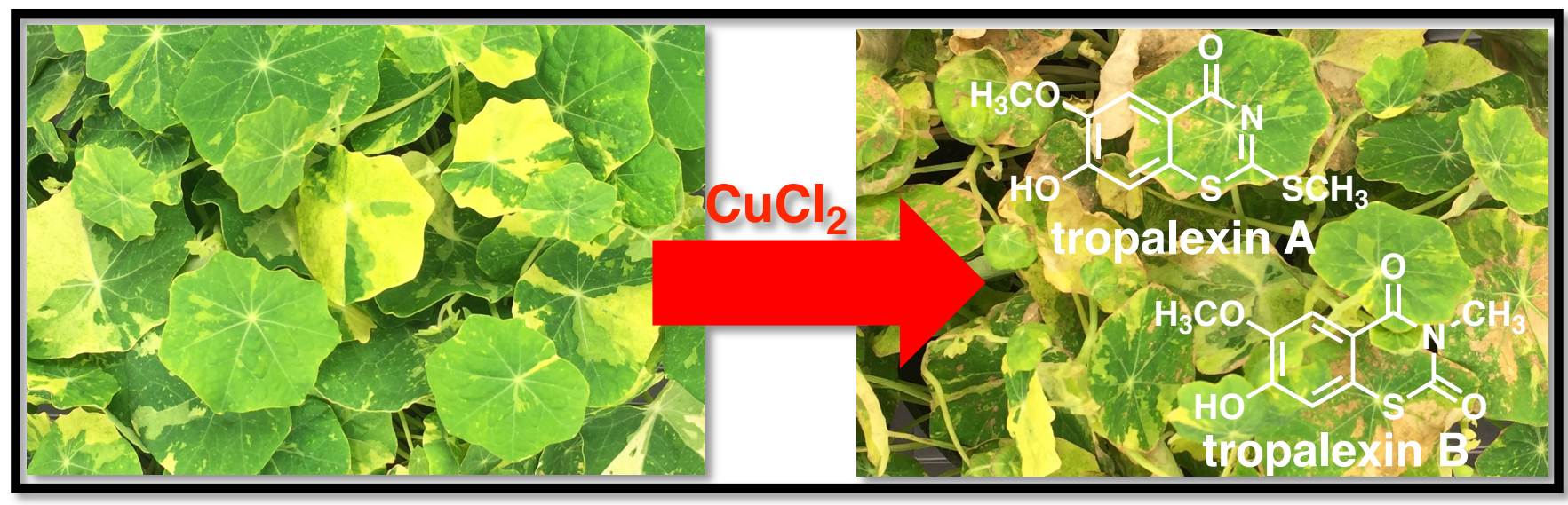

\section{Abstract}

Tropalexins A and B, the first phytoalexins isolated from Tropaeolum majus (Brassicales order, Tropaeolaceae family), together with their antifungal activity and biosynthetic precursors are disclosed. These plant defenses contain a 1,3-benzothiazine ring and are shown to derive from Phe via the glucosinolate glucotropaeolin, which indicates that $T$. majus employs a phytoalexin biosynthetic pathway closely related to the pathway operating in Brassica spp. (Brassicales order, Brassicaceae family) and suggests an evolutionary conservation of key biosynthetic enzymes.

Key words: Brassicales; Brassicaceae; Tropaeolaceae; Tropaeolum majus; crucifer; phytoalexin; tropalexins $A$ and $B$ 


\section{Introduction}

Microbial infections and other stresses such as heavy metal salts and UV radiation stimulate plants to produce de novo specialized metabolites that display antimicrobial activity and are defined as phytoalexins (Bailey and Mansfield, 1982; Kuc, 1995; VanEtten et al., 1994). Plant resistance to infection by microbial pathogens depends on numerous events occurring immediately after pathogen attack, including the rate and amount of phytoalexin production. In general, phytoalexins within phylogenetically related groups are formed from common precursor(s) using co-dependent biosynthetic pathways. Current progress in this dynamic research area is unwrapping opportunities to design more robust and environmentally safer strategies for crop protection. Undeniably, investigation of the phytoalexins produced by crucifers (order Brassicales, family Brassicaceae) has generated more than 55 chemical structures since the first report appeared in 1986 (Takasugi et al., 1986; Pedras et al. 2011; Pedras and Abdoli, 2017). The variety of unique chemical structures, most of which contain nitrogen and sulfur, expanded tremendously the phytoalexin chemical space. However, in spite of such a structural variety, most of these metabolites, including the phytoalexins brassinin (2), cyclobrassinin (3) and rutalexin (4), are biosynthesized from a common amino acid precursor, tryptophan (Trp), via the indole glucosinolate glucobrassicin (1) (Pedras et al., 2011). More recently, the isolation of nasturlexins A (6) and C (7) from Nasturtium officinale L., Barbarea vulgaris $\mathrm{R}$. Br. and B. verna (P. Mill.) Aschers (all from the family Brassicaceae) (Pedras and To, 2015; Pedras et al., 2015) has established that other cruciferous phytoalexins derive from the aromatic amino acid homophenylalanine (homoPhe) (Pedras and To, 2018b). It is worth mentioning that $\mathrm{N}$. officinale is the only plant species reported to date containing phytoalexins from both Trp (e.g., 2) (Pedras and To, 2016) and homoPhe (e.g., 6) pathways (Pedras and To, 2015). As summarized in Fig. 1 , the glucosinolate gluconasturtiin (5) is an intermediate in the biosynthetic pathway of nasturlexins 6 and 7. 

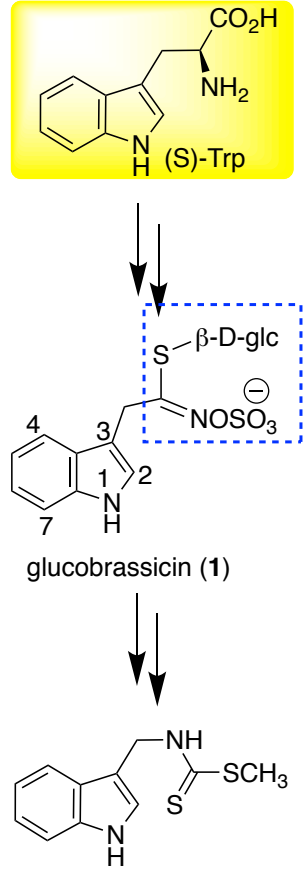

brassinin (2)

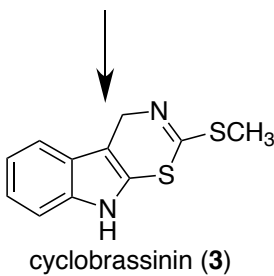

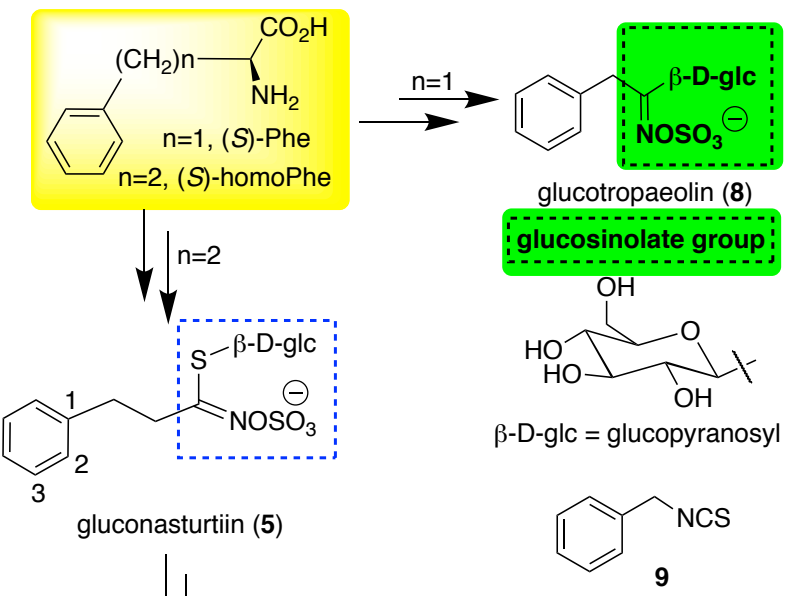

$\downarrow \downarrow$
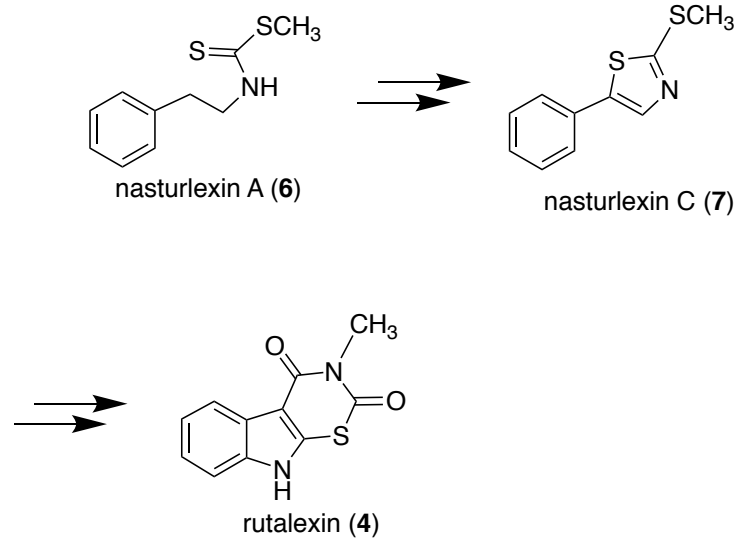

Fig. 1. Biosynthetic pathways of Brassica spp. phytoalexins derived from (S)-Trp: brassinin (2), cyclobrassinin (3) and rutalexin (4) and Nasturtium officinale phytoalexins derived from (S)homoPhe: nasturlexins $A(6)$ and $C(7)$.

The order Brassicales encompasses 17 families, all of which are known to produce a variety of glucosinolates (Blazevic et al., 2020), including the most economically valuable Brassicaceae (Edger et al. 2018). Notably, although glucosinolates derive from both aliphatic and aromatic amino acids (Blazevic et al., 2020), so far, the phytoalexins found in Brassicaceae derive only from aromatic amino acids (Trp, homoPhe) (Pedras and To, 2018b). However, considering that to date only the family Brassicaceae has been investigated for phytoalexin production (Pedras et al., 2011), it is not known whether other families within the Brassicales use different amino acid precursors. For this reason, to broaden the knowledge of the phytoalexins produced within the Brassicales, nasturtium (Tropaeolum majus L.), a member of the family Tropaeolaceae (order Brassicales), was investigated for phytoalexin production. Nasturtium is an edible plant with bright colored flowers native to South America but cultivated worldwide. Due to a peppery 
flavor, its leaves are used for salads, whereas leaf infusions are used to treat infections, hypertension, asthma, constipation, and cardiovascular disorders. Hence, it is not surprising to find numerous studies addressing both the nutritional and medicinal value of nasturtium plants (Jakubczyk et al., 2018; Bazylko et al., 2013; Gasparotto et al., 2011). Remarkably, T. majus has facilitated and instigated pioneering work that led to the discovery of the complete biosynthetic pathway of glucotropaeolin (8) (Du and Halkier, 1996).

More than three decades after the first report on Brassicaceae phytoalexins, the first phytoalexins from Tropaeolaceae are uncovered in work reported here. Two new phytoalexins produced by $T$. majus are disclosed together with their antifungal activity and biosynthetic precursors. The discovery of the first phytoalexins from Tropaeolaceae that are derived from Phe via glucotropaeolin (8) and benzylisothiocyanate (9), suggests that $T$. majus uses a biosynthetic pathway similar to that followed in Brassica spp., well-known as cruciferous phytoalexins.

\section{Results and discussion}

\subsection{Isolation, structure elucidation and quantification of elicited metabolites}

Nasturtium plants were grown, elicited (aq. $\mathrm{CuCl}_{2}$ spray) and incubated for various times, the leaves were cut, frozen in liquid nitrogen, and extracted with organic solvents, as detailed in the experimental section. Leaves of control plants $\left(\mathrm{H}_{2} \mathrm{O}\right.$ spray) were treated similarly. The leaf extracts of $\mathrm{CuCl}_{2}$ - elicited and control plants were analyzed by HPLC-DAD-ESI-MS to track down elicited metabolites. The resulting chromatograms revealed several peaks present in chromatograms of elicited extracts that were not detected in chromatograms of control extracts. These results suggested that additional metabolites were biosynthesized after elicitation of plants with $\mathrm{CuCl}_{2}$ (Figs. S1 and S2, Supporting Information). The UV spectra of elicited components were not available in our HPLC-DAD-MS libraries, except for a peak corresponding to the readily identifiable plant metabolite benzylisothiocyanate $\left(9, t_{R}=22.7 \mathrm{~min}\right.$, commercially available).

Next, to isolate the unknown components from elicited leaf extracts, additional experiments using larger amounts of elicited leaves were carried out as described in the experimental section. Two compounds named tropalexins $A(10)$ and $B(11)$ were isolated in sufficient amounts to establish their chemical structures by analyses of NMR spectroscopic data and HR-ESI-MS, as follows. 
The HR-ESI-MS spectrum of tropalexin $A\left(10, t_{R}=6.2 \mathrm{~min}\right)$ displayed a quasi-molecular ion at $\mathrm{m} / \mathrm{z} 256.0104[\mathrm{M}+\mathrm{H}]^{+}$consistent with the molecular formula $\mathrm{C}_{10} \mathrm{H}_{9} \mathrm{NO}_{3} \mathrm{~S}_{2}$, whereas that of tropalexin $B\left(11, t_{R}=7.8 \mathrm{~min}\right)$ showed a quasi-molecular ion at $\mathrm{m} / \mathrm{z} 238.0178[\mathrm{M}-\mathrm{H}]^{-}$consistent with the molecular formula $\mathrm{C}_{10} \mathrm{H}_{9} \mathrm{NO}_{4} \mathrm{~S}$. These molecular formulas differed by 16 m.u. and suggested seven degrees of unsaturation in each structure. In agreement with each molecular formula, the ${ }^{1} \mathrm{H}$ NMR spectra of both compounds displayed signals of nine protons (two methyl groups, two aromatic singlets and an exchangeable proton), while the ${ }^{13} \mathrm{C}$ NMR spectra showed 10 signals (two methyl carbons and eight $\mathrm{sp}^{2}$ carbons, two of which were protonated, Table 1). Analyses of 2D-NMR data (HMBC and HSQC) of both compounds suggested the presence of a 1,2,4,5-tetrasubstituted benzene ring containing $\mathrm{CH}_{3} \mathrm{O}$ and $\mathrm{OH}$ groups in adjacent positions. In addition to the four unsaturations due to benzene moieties, rings containing a 2(methylthio)thiazin-4-one in tropalexin A (10, 7-hydroxy-6-methoxy-2-(methylthio)-4H-1,3benzothiazin-4-one) and a 1,3-benzothiazine-2,4-dione in tropalexin B (11, 7-hydroxy-6-methoxy$2 \mathrm{H}$-1,3-benzothiazine-2,4(3H)-dione) were consistent with the spectroscopic data. Furthermore, NOE experiments demonstrated that the $\mathrm{CH}_{3} \mathrm{O}$ group was adjacent to $\mathrm{H}-5$, as summarized in Fig. 2.
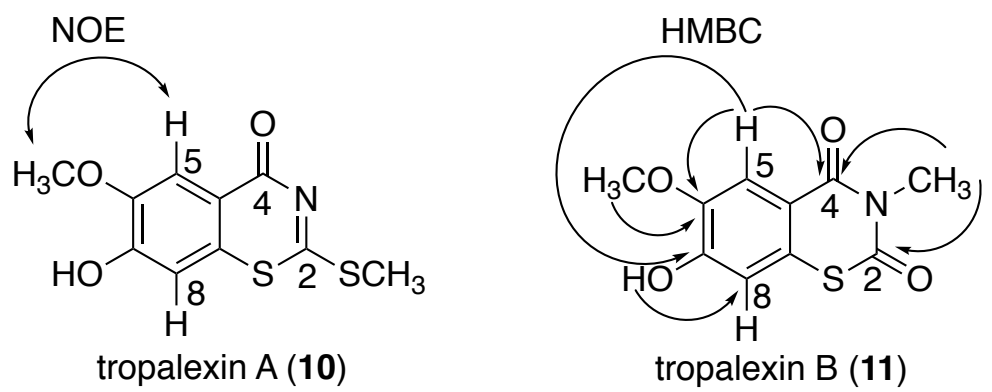

Fig. 2. Selected NOE and HMBC correlations observed in spectra of tropalexins $A(\mathbf{1 0})$ and $B$ (11). 
Table 1. ${ }^{1} \mathrm{H}(600 \mathrm{MHz})$ and ${ }^{13} \mathrm{C}$ NMR $(150 \mathrm{MHz})$ chemical shifts $(\delta)$ of tropalexins $\mathrm{A}(\mathbf{1 0})$ and $\mathrm{B}$ (11) (spectra obtained in $\mathrm{CDCl}_{3}$ ).

\begin{tabular}{l|l|l|l|l}
\hline Position & \multicolumn{2}{|c|}{$\delta \mathrm{H}$ (multiplicity) } & \multicolumn{2}{c}{$\delta \mathrm{c}$} \\
\hline & 10 & 11 & 10 & 11 \\
2 & --- & --- & 166.2 & 165.1 \\
4 & --- & --- & 177.5 & 163.5 \\
$4 a$ & --- & --- & 118.9 & 115.4 \\
5 & $7.93(\mathrm{~s})$ & $7.83(\mathrm{~s})$ & 111.6 & 112.4 \\
6 & --- & --- & 150.6 & 146.5 \\
7 & --- & --- & 150.6 & 151.5 \\
8 & $6.86(\mathrm{~s})$ & $6.81(\mathrm{~s})$ & 109.7 & 109.7 \\
$8 \mathrm{a}$ & --- & --- & 129.6 & 126.5 \\
$\mathrm{OH}$ & $6.28(\mathrm{~s})$ & $6.24(\mathrm{~s})$ & --- & --- \\
$\mathrm{OCH}_{3}$ & $4.03(\mathrm{~s})$ & $4.00(\mathrm{~s})$ & 56.8 & 56.7 \\
$\mathrm{NCH}_{3}$ & --- & $3.52(\mathrm{~s})$ & --- & 29.3 \\
$\mathrm{SCH}_{3}$ & $2.74(\mathrm{~s})$ & --- & 14.5 & --- \\
\hline
\end{tabular}

Quantification of tropalexins A (10) and B (11) produced up to $120 \mathrm{~h}$ post-elicitation was carried out by HPLC-DAD using calibration curves built with each compound. As shown in Fig. 3, the amounts ( $\mu$ moles $/ 100 \mathrm{~g}$ of fresh tissue) of tropalexin A (10) increased considerably from $24 \mathrm{~h}$ $(14 \pm 4 \mu$ moles $/ 100 \mathrm{~g})$ up to $72 \mathrm{~h}(43 \pm 30 \mu$ moles $/ 100 \mathrm{~g})$ post-elicitation, while the amounts of tropalexin B (11) remained lower, even $120 \mathrm{~h}$ post-elicitation $(12 \pm 5 \mu \mathrm{moles} / 100 \mathrm{~g})$.

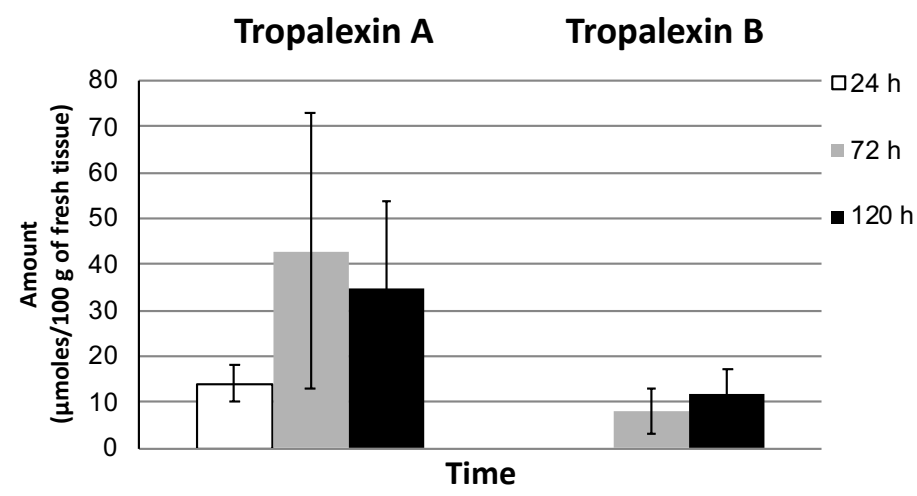

Fig. 3. Amounts of tropalexins $A(\mathbf{1 0})$ and $B$ (11) (averages of three experiments, triplicate samples) detected in elicited leaves of Tropaeolum majus (HPLC-DAD analysis, method A, detection at $220 \mathrm{~nm}$ ). 
A chemical structure search revealed that compounds closely related to tropalexins $A(10)$ and $B(11)$, bretschneiderazines $A$ (12) and B (13), had been reported in Bretschneidera sinensis Hemsl. (Brassicales, family Akaniaceae) (Liu et al., 2010). B. sinensis is a rare evergreen tree found in south and east China, Taiwan, northern Thailand and Vietnam, whose bark is used in Chinese medicine to treat arthralgia and myalgia. As well, $B$. sinensis was shown to produce benzyl, hydroxybenzyl, dihydroxybenzyl, methoxybenzyl and 3-hydroxy-4-methoxybenzyl glucosinolates in various organs, including leaves and fruits (Montaut et al., 2015). However, considering that phylogenetic studies support the sister-family pair Tropaeolaceae-Akaniaceae (Edger et al., 2018), it is not surprising to find that species within this sister-family pair produce structurally related metabolites.
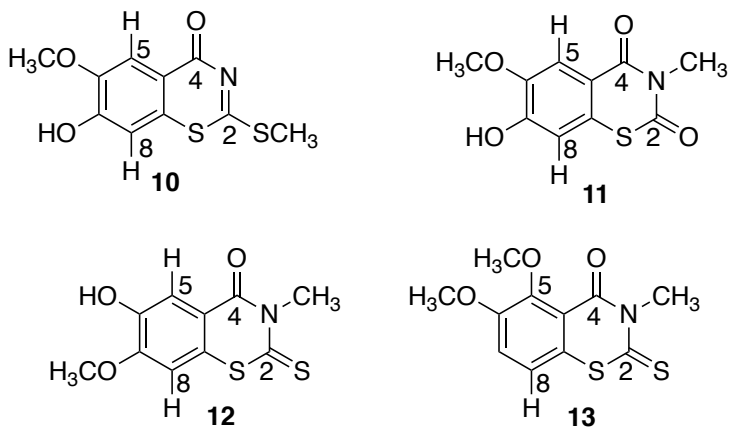

Fig. 4. Structures of tropalexins $A(10)$ and $B$ (11) from Tropaeolum majus (Tropaeolaceae) and bretschneiderazines A (12) and B (13) from Bretschneidera sinensis (family Akaniaceae).

\subsection{Antifungal activity}

The antifungal activities of tropalexins $A(10)$ and $B(11)$ were tested using a fungal radial growth assay, against the following phytopathogenic fungal species: Alternaria brassicicola (Schwein.) Wiltshire and Leptosphaeria maculans (Desm.) Ces. et de Not. [asexual stage Phoma lingam (Tode ex Fr.) Desm., both specific pathogens of Brassica species, and the generalist plant pathogen Sclerotinia sclerotiorum (Lib.) de Bary that infects numerous plant species including Brassicales spp. (Pedras et al., 2015). As standard practice, the phytoalexin camalexin (14) (Pedras and Abdoli,2018) was used as the positive control, since it is one of the most antifungal of the cruciferous phytoalexins (Pedras et al., 2011). While tropalexins A (10) and B (11) displayed similar inhibitory activity against $A$. brassicicola and $S$. sclerotiorum, tropalexin B (11) was significantly more inhibitory to $L$. maculans and camalexin (14) displayed the highest inhibitory 
activity against each fungal species.

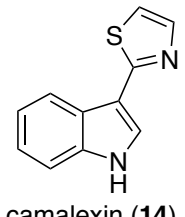

camalexin (14)

Table 2. Antifungal activity of tropalexins $A(10)$ and $B(11)$ and camalexin (14) against the fungal pathogens: Alternaria brassicicola, Leptosphaeria maculans and Sclerotinia sclerotiorum.

\begin{tabular}{|c|c|c|c|}
\hline \multirow{2}{*}{ Compound } & \multicolumn{3}{|c|}{$\%$ Inhibition ${ }^{a} \pm$ Standard Deviation } \\
\hline & A. brassicicola & L. maculans & S. sclerotiorum \\
\hline Tropalexin A (10) & & & \\
\hline $0.50 \mathrm{mM}$ & $87 \pm 4^{d}$ & $69 \pm 0^{f}$ & $85 \pm 0^{d}$ \\
\hline $0.25 \mathrm{mM}$ & $69 \pm 0^{f}$ & $54 \pm 0^{h}$ & $50 \pm 4^{g}$ \\
\hline $0.10 \mathrm{mM}$ & $52 \pm 4^{g}$ & $33 \pm 4^{\mathrm{i}, \mathrm{j}, \mathrm{k}}$ & $35 \pm 4^{h}$ \\
\hline Tropalexin B (11) & & & \\
\hline $0.50 \mathrm{mM}$ & $81 \pm 4^{\mathrm{d}, \mathrm{e}}$ & $81 \pm 4^{e}$ & $91 \pm 4^{d}$ \\
\hline $0.25 \mathrm{mM}$ & $62 \pm 0^{f}$ & $40 \pm 4^{i}$ & $61 \pm 4^{f}$ \\
\hline $0.10 \mathrm{mM}$ & $33 \pm 4^{\mathrm{h}}$ & $25 \pm 4^{\mathrm{k}, \mathrm{l}}$ & $30 \pm 4^{h}$ \\
\hline Camalexin $(14)^{\mathrm{b}}$ & & & \\
\hline $0.50 \mathrm{mM}$ & --- & $100 \pm 0^{c}$ & --- \\
\hline $0.25 \mathrm{mM}$ & $100 \pm 0^{c}$ & $65 \pm 4^{f, g}$ & --- \\
\hline $0.10 \mathrm{mM}$ & $79 \pm 4^{e}$ & $33 \pm 4, \mathrm{i}, \mathrm{j}, \mathrm{k}$ & $100 \pm 0^{c}$ \\
\hline
\end{tabular}

a Percentage of growth inhibition calculated using the formula: \% inhibition $=100-[$ (growth on amended/growth in control) $\times 100$ ]; values represent the mean and standard deviation of two independent experiments conducted in tetraplicate. Data from each treatment were analyzed with one-way ANOVA; differences among treatment means were detected with a Tukey HSD test; $n$ $=4$; different superscript letters in the same column $(\mathrm{c}-\mathrm{I})$ indicate significant differences $(P<0.05)$.

b Positive control.

2.3 Biosynthetic origin: feeding experiments with isotopically labeled compounds and analyses of isotope incorporations

Results of previous work dealing with the biosynthetic pathway of nasturlexin $A(6)$ and related metabolites (Pedras and To, 2018b), coupled with a retrobiosynthetic analysis of tropalexins $A(\mathbf{1 0})$ and $B(11)$ suggest that benzylisothiocyanate (9) and the corresponding methyl 
dithiocarbamate 15 are biosynthetic precursors of both 10 and 11 . To substantiate this hypothesis, the stable isotopes deuterium (D) and ${ }^{15} \mathrm{~N}$ were employed to label both precursors (Fig. 5) since $\mathrm{D}$ and ${ }^{15} \mathrm{~N}$ incorporation into each metabolite can be measured consistently using analytical instruments (HPLC-ESI-MS, HPLC-ESI-HR-MS and GC-FI-HR-MS). Isotopically labeled compounds have been numbered identically to non-labeled compounds followed by a letter,with different letters indicating different isotopic composition, e.g., 10a and 10b.
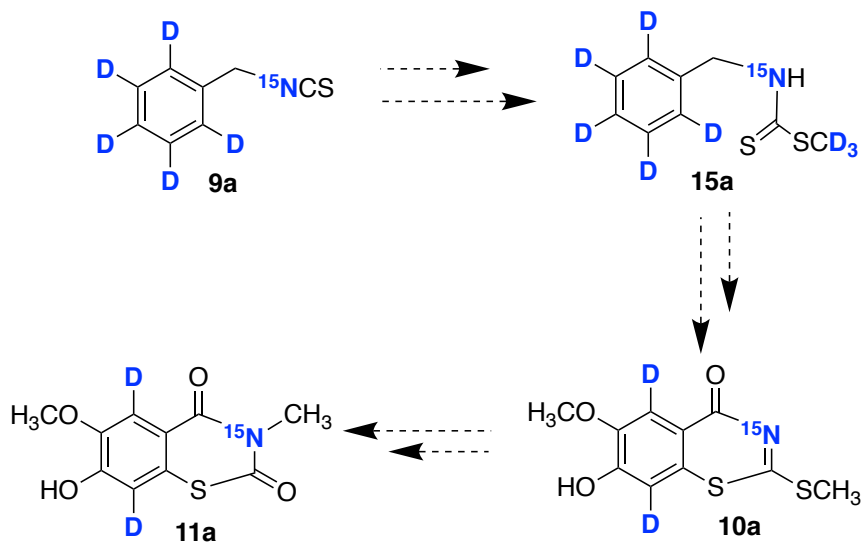

Fig. 5. Potential biosynthetic intermediates of tropalexins $A(10 / 10 a)$ and $B(11 / 11 a)$ in Tropaeolum majus.

The isotopically labelled benzylisothiocyanate (9a) and methyl benzyldithiocarbamate 15a were synthesized (Pedras and To, 2018a) as summarized in Fig. 6 and reported in Supplementary Information. The purity and percentage of isotope content of synthetic compounds were confirmed by ${ }^{1} \mathrm{H}$ NMR and ESI-HR-MS, respectively.

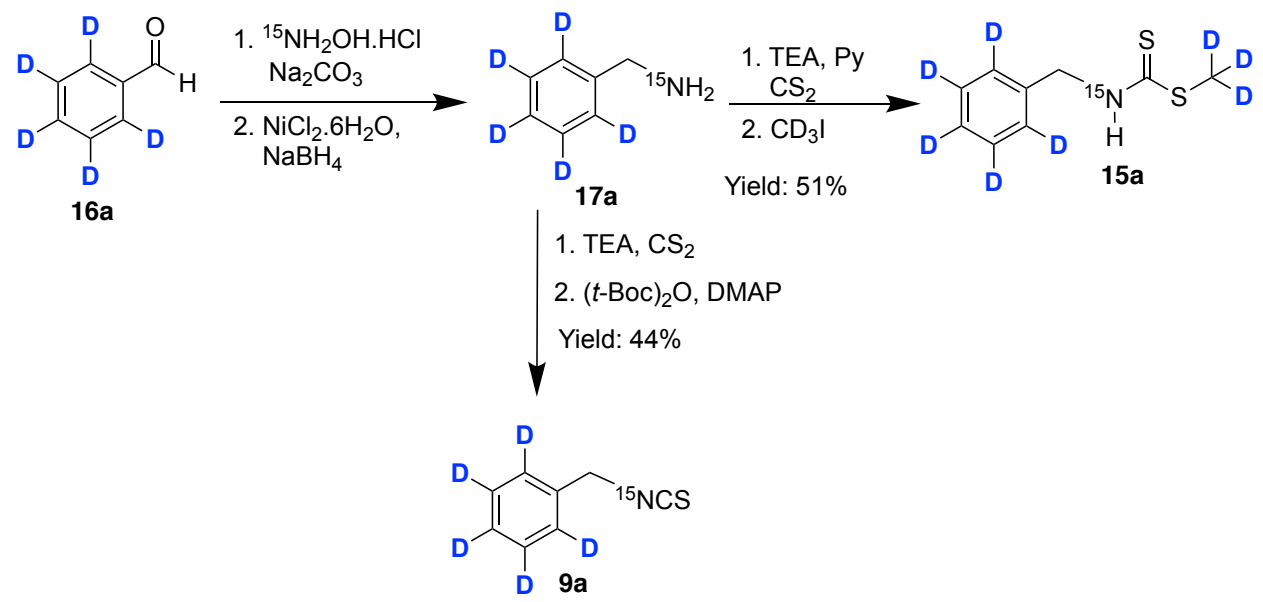

Fig. 6. Synthesis of $\left[2,3,4,5,6-{ }^{2} \mathrm{H}_{5},{ }^{15} \mathrm{~N}\right]$ benzylisothiocyanate (9a) and $\left[{ }^{2} \mathrm{H}_{3} \mathrm{CS}\right] \mathrm{methyl}[2,3,4,5,6-$ $\left.{ }^{2} \mathrm{H}_{5},{ }^{15} \mathrm{~N}\right]$ benzyldithiocarbamate (15a). 
Next, petiolated leaves of elicited plants were immersed separately in aqueous solutions containing $9 \mathbf{a}$ or $15 \mathbf{a}$ and incubated as detailed in the experimental section. Control samples (two separate groups: elicited leaves fed with non-labelled compounds and non-elicited leaves fed with water) were treated similarly. After incubation, leaves were frozen in liq. nitrogen and extracted as described in the experimental section. The $\mathrm{CH}_{2} \mathrm{Cl}_{2}$ extracts were analyzed by HPLC-DAD-ESIMS and phytoalexins and other metabolites were identified by comparison of their HPLC-DADESI-MS data (UV spectra, $\mathrm{m} / \mathrm{z}$ ions and retention times) with those of authentic synthetic samples. The percentages of isotope incorporation of compounds $9 a$ and $15 a$ into tropalexins $A(10)$ and B (11) were determined using ion-peak intensities (\%) obtained in ESI-MS (Figs. 7 and 8), according to equations reported in the corresponding Tables 3 (compound 9a) and 4 (compound 15a). For each feeding experiment, isotope incorporations were further confirmed by HPLC-ESIHR-MS.

\section{3. $1\left[2,3,4,5,6-{ }^{2} \mathrm{H}_{5},{ }^{15} \mathrm{~N}\right]$ Benzylisothiocyanate (9a)}

The ESI-MS spectra of the extracts of leaves incubated with [2,3,4,5,6$\left.{ }^{2} \mathrm{H}_{5},{ }^{15} \mathrm{~N}\right]$ benzylisothiocyanate $(9 \mathrm{a})$ showed a peak corresponding to $\left[5,8-{ }^{2} \mathrm{H}_{2},{ }^{15} \mathrm{~N}\right]$ tropalexin $\mathrm{A}$ (10a) at $\mathrm{m} / \mathrm{z} 259.2[\mathrm{M}+\mathrm{H}+3]^{+}$, plus the expected peaks corresponding to natural abundance tropalexin A (10) at $\mathrm{m} / \mathrm{z} 256.1[\mathrm{M}+\mathrm{H}]^{+}, 257.1[\mathrm{M}+\mathrm{H}+1]^{+}$and $258.2[\mathrm{M}+\mathrm{H}+2]^{+}$(Fig. $7 \mathrm{~B}$ ). ESI-MS spectra of control samples showed only ion peaks corresponding to natural abundance tropalexin A (10) (Fig. 7 A). The percentage of isotope incorporation of [2,3,4,5,6$\left.{ }^{2} \mathrm{H}_{5},{ }^{15} \mathrm{~N}\right]$ benzylisothiocyanate $(\mathbf{9 a})$ into $\left[5,8-{ }^{2} \mathrm{H}_{2},{ }^{15} \mathrm{~N}\right]$ tropalexin $\mathrm{A}(\mathbf{1 0 a})$ after $24 \mathrm{~h}$ of incubation was calculated to be $7.2 \pm 2.0 \%$ (Table 3 ). Tropalexin B (11) was detected only in negative mode in very small amount, whereas 11 a was not detected (i.e., no isotope incorporation detected). 

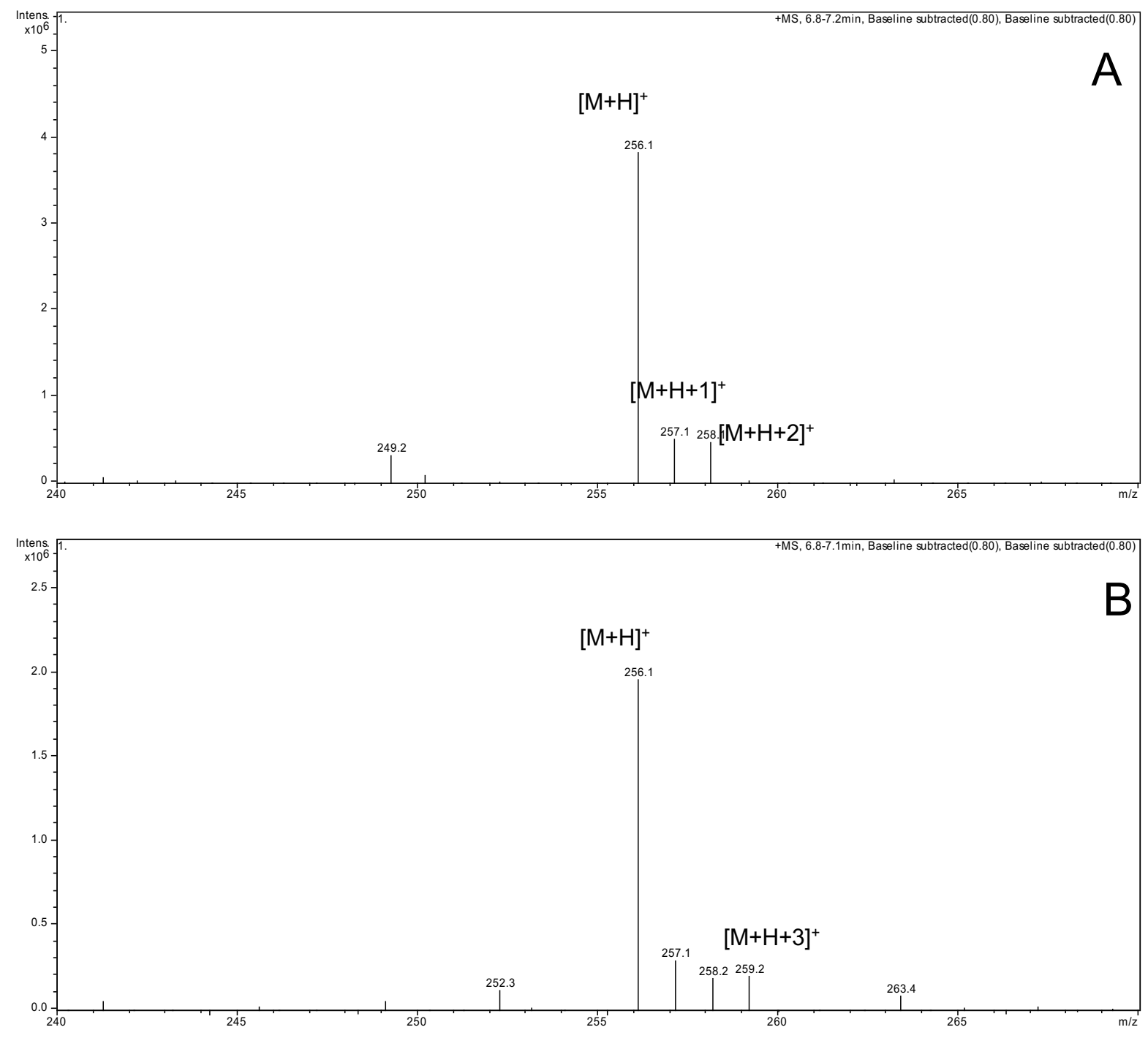

Fig. 7. ESI-MS spectra (positive mode) of tropalexin A (10 and 10a): A, elicited leaves incubated with non-labeled benzylisothiocyanate (9) for $24 \mathrm{~h}$; B, elicited leaves incubated with $[2,3,4,5,6$ $\left.{ }^{2} \mathrm{H}_{5},{ }^{15} \mathrm{~N}\right]$ benzylisothiocyanate (9a) for $24 \mathrm{~h}$. 
Table 3. Metabolism and incorporation of $\left[2,3,4,5,6-{ }^{2} \mathrm{H}_{5},{ }^{15} \mathrm{~N}\right]$ benzylisothiocyanate (9a) $24 \mathrm{~h}$ post elicitation.

\begin{tabular}{l|l|l|l}
\hline $\begin{array}{l}\text { Metabolites in elicited leaf } \\
\text { extracts }\end{array}$ & $\begin{array}{l}\text { \% lon peak intensity } \pm \\
\text { SD }\end{array}$ & $\%$ Incorporation $\pm \mathrm{SD}^{\mathrm{a}}$ & $\begin{array}{l}\text { Amount }^{\mathrm{b}} \\
\mathbf{1 0}+1 \mathbf{1 0 a}\end{array}$ \\
\hline $\begin{array}{l}{\left[5,8-{ }^{2} \mathrm{H}_{2},{ }^{15} \mathrm{~N}\right] \text { Tropalexin } \mathrm{A}(\mathbf{1 0 a})} \\
\mathrm{C}_{10} \mathrm{H}_{8}{ }^{2} \mathrm{H}_{2}{ }^{15} \mathrm{NO}_{3} \mathrm{~S}_{2}, \mathrm{~m} / \mathrm{z} 259.2\end{array}$ & {$[\mathrm{M}+\mathrm{H}+3]^{+}=7.8 \pm 3.0$} & $\begin{array}{l}\%=[7.8 /(100+7.8)] \times 100)= \\
7.2 \pm 2.0 \%\end{array}$ & $\leq 2.3$ \\
\hline $\begin{array}{l}\text { Tropalexin A (10) } \\
\mathrm{C}_{10} \mathrm{H}_{10} \mathrm{NO}_{3} \mathrm{~S}_{2}, \mathrm{~m} / \mathrm{z} 256.1\end{array}$ & {$[\mathrm{M}+\mathrm{H}]^{+}=100 \pm 0$} & --- & \\
\hline
\end{tabular}

a \% Isotope incorporation calculated from HPLC-ESI-MS (peak intensities in positive mode); \% of incorporation $=\left\{[\mathrm{M}+\mathrm{H}+3]^{+} /\left([\mathrm{M}+\mathrm{H}]^{+}+[\mathrm{M}+\mathrm{H}+3]^{+}\right)\right\} \times 100$, where $\mathrm{n}=$ number of ${ }^{2} \mathrm{H}$ plus ${ }^{15} \mathrm{~N}$ atoms; values represent the mean and standard deviation of triplicate samples.

${ }^{\mathrm{b}}$ Amount ( $\mu$ moles/100 $\mathrm{g}$ of fresh tissue); values represent the mean of triplicate samples.

\subsection{2 $\left[{ }^{2} \mathrm{H}_{3} \mathrm{CS}\right]$ Methyl $\left[2,3,4,5,6-{ }^{2} \mathrm{H}_{5},{ }^{15} \mathrm{~N}\right] \mathrm{benzyldithiocarbamate}$ (15a)}

ESI-MS spectra of the extracts of leaves incubated with $\left[{ }^{2} \mathrm{H}_{3} \mathrm{CS}\right]$ methyl $[2,3,4,5,6-$ $\left.{ }^{2} \mathrm{H}_{5},{ }^{15} \mathrm{~N}\right]$ benzyldithiocarbamate (15a) showed a peak corresponding to $\left[{ }^{2} \mathrm{H}_{3} \mathrm{CS}, 5,8\right.$ $\left.{ }^{2} \mathrm{H}_{2},{ }^{15} \mathrm{~N}\right]$ tropalexin $\mathrm{A}(\mathbf{1 0 b})$ at $\mathrm{m} / \mathrm{z} 262.0[\mathrm{M}+\mathrm{H}+6]^{+}$, plus peaks corresponding to natural abundance tropalexin A (10) at $\mathrm{m} / \mathrm{z} 256.0[\mathrm{M}+\mathrm{H}]^{+}, 256.9[\mathrm{M}+\mathrm{H}+1]^{+}$and $258.0[\mathrm{M}+\mathrm{H}+2]^{+}$(Fig. $8 \mathrm{~B}$ ). ESI-MS analyses of control samples showed only the expected ion peaks corresponding to natural abundance tropalexin A (10) (Fig. 8 A). The percentage of incorporation of 15a into tropalexin A (10b) after $24 \mathrm{~h}$ and $48 \mathrm{~h}$ of incubation was calculated to be $5.8 \pm 1.5 \%$ and $23.3 \pm 5.2 \%$, respectively (Table 4). Again, in these experiments tropalexin $B(11)$ was detected in negative ion mode in very small amount, whereas $11 \mathrm{~b}$ was not detected, (i.e., no isotope incorporation was detected). 

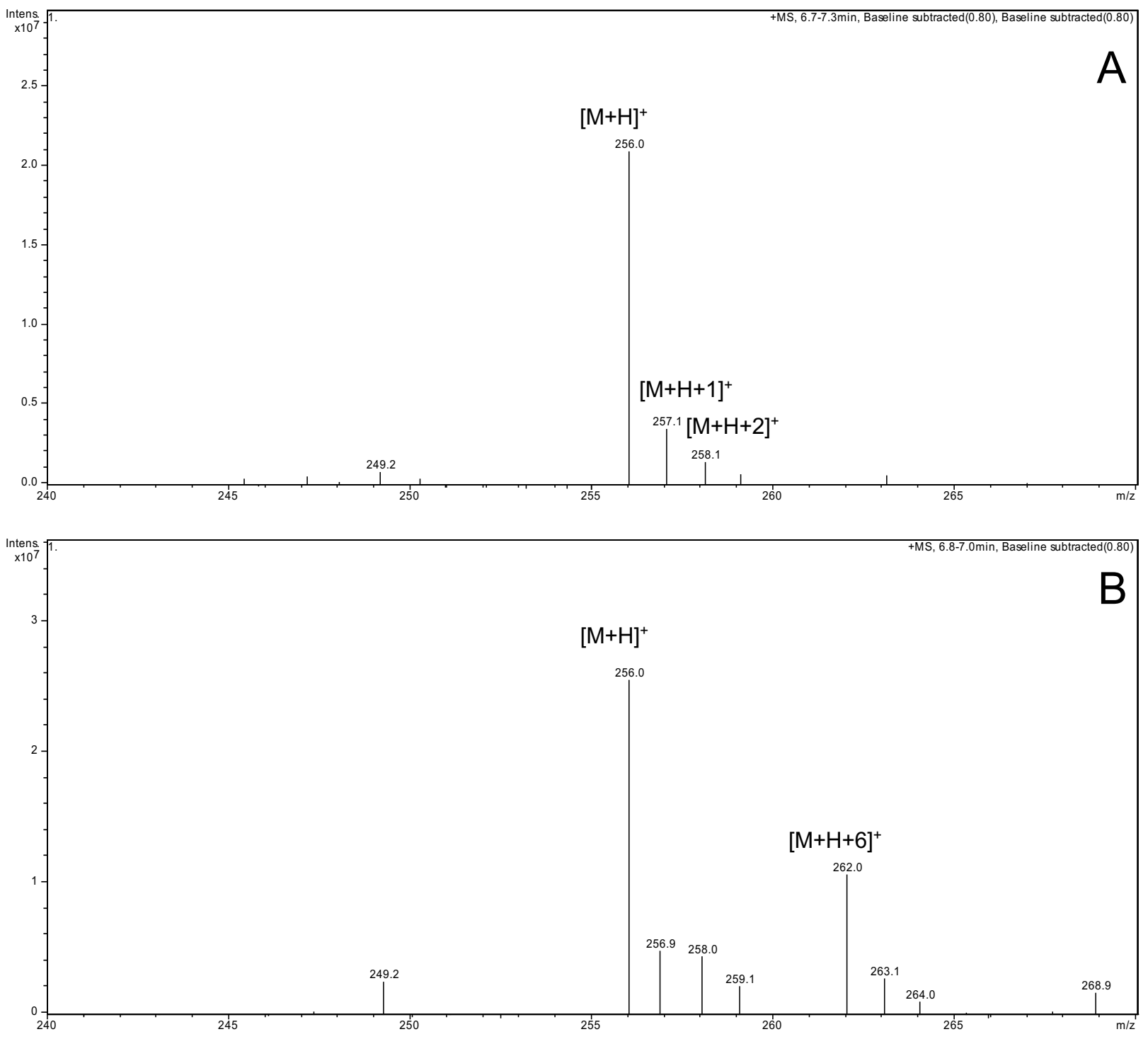

Fig. 8. ESI-MS spectra (positive mode) of tropalexin $A$ (10 and 10b): $A$, elicited leaves incubated with non-labeled methyl benzyldithiocarbamate (15) for $48 \mathrm{~h}$; B, elicited leaves incubated with $\left[{ }^{2} \mathrm{H}_{3} \mathrm{CS}\right]$ methyl $\left[2,3,4,5,6-{ }^{2} \mathrm{H}_{5},{ }^{15} \mathrm{~N}\right]$ benzyldithiocarbamate (15a) for $48 \mathrm{~h}$. 
Table 4. Metabolism and incorporation of $\left[{ }^{2} \mathrm{H}_{3} \mathrm{CS}\right]$ methyl $\left[2,3,4,5,6-{ }^{2} \mathrm{H}_{5},{ }^{15} \mathrm{~N}\right]$ benzyldithiocarbamate (15a) $24 \mathrm{~h}$ and $48 \mathrm{~h}$ post elicitation.

\begin{tabular}{|c|c|c|c|}
\hline Metabolites in elicited leaf extracts & $\begin{array}{l}\text { Incubation time }(\mathrm{h}) ; \% \\
\text { ion peak intensity } \pm \\
\text { SD }\end{array}$ & $\%$ Incorporation $\pm S D^{a}$ & $\begin{array}{l}\text { Amount }^{b} \\
10+10 b\end{array}$ \\
\hline $\begin{array}{l}{\left[{ }^{2} \mathrm{H}_{3} \mathrm{CS}, 5,8-{ }^{2} \mathrm{H}_{2},{ }^{15} \mathrm{~N}\right] \text { Tropalexin A }} \\
\text { (10b) } \mathrm{C}_{10} \mathrm{H}_{5}{ }^{2} \mathrm{H}_{5}{ }^{15} \mathrm{NO}_{3} \mathrm{~S}_{2}, \mathrm{~m} / \mathrm{z} 262.0\end{array}$ & $\begin{array}{l}24 \mathrm{~h},[\mathrm{M}+\mathrm{H}+6]^{+}=6.2 \pm \\
2.1 \\
48 \mathrm{~h},[\mathrm{M}+\mathrm{H}+6]^{+}=30.4 \\
\pm 11.4\end{array}$ & $\begin{array}{l}\%=[6.2 /(100+6.2)] \times 100)= \\
5.8 \pm 1.5 \\
\%=[30.4 /(100+30.4)] \times 10 \\
0)=23.3 \pm 5.2\end{array}$ & $\begin{array}{l}\leq 2.3 \\
3.6 \pm 0.2\end{array}$ \\
\hline $\begin{array}{l}\text { Tropalexin A (10) } \\
\mathrm{C}_{10} \mathrm{H}_{10} \mathrm{NO}_{3} \mathrm{~S}_{2}, \mathrm{~m} / \mathrm{z} 256.0\end{array}$ & $\begin{array}{l}24 \mathrm{~h} ;[\mathrm{M}+\mathrm{H}]^{+}=100 \pm 0 \\
48 \mathrm{~h} ;[\mathrm{M}+\mathrm{H}]^{+}=100 \pm 0\end{array}$ & --- & $3.6 \pm 0.2$ \\
\hline
\end{tabular}

a \% Isotope incorporation calculated from HPLC-ESI-MS (peak intensities in positive mode); \% of incorporation $=\left\{[\mathrm{M}+\mathrm{H}+6]^{+} /\left([\mathrm{M}+\mathrm{H}]^{+}+[\mathrm{M}+\mathrm{H}+6]^{+}\right)\right\} \times 100$, where $\mathrm{n}=$ number of ${ }^{2} \mathrm{H}$ plus ${ }^{15} \mathrm{~N}$ atoms; values represent the mean and standard deviation of triplicate samples.

${ }^{\mathrm{b}}$ Amount ( $\mu$ moles $/ 100 \mathrm{~g}$ of fresh tissue \pm standard deviation); values represent the mean and standard deviation of triplicate samples.

Altogether our results indicate that benzylisothiocyanate (9) and methyl benzyldithiocarbamate (15) are precursors of tropalexin A (10). Consequently, by analogy to nasturlexins $A(6)$ and $B(7)$, it is inferred that Phe via glucotropaeolin (8) (and/or its hydroxy and methoxy counterparts) is the primary precursor of 10. As expected, the percentage of incorporation of $\left[2,3,4,5,6-{ }^{2} \mathrm{H}_{5},{ }^{15} \mathrm{~N}\right]$ benzylisothiocyanate $(9 \mathrm{a})$ into tropalexin $\mathrm{A}(\mathbf{1 0})$ is lower than that of $\left[{ }^{2} \mathrm{H}_{3} \mathrm{CS}\right]$ methyl $\left[2,3,4,5,6-{ }^{2} \mathrm{H}_{5},{ }^{15} \mathrm{~N}\right]$ benzyldithiocarbamate (15a) mostly because 9a is diluted with the natural abundance benzylisothiocyanate (9) produced in the leaf tissues in higher amounts than 15. Because tropalexin B (11) was produced in very low amounts, it was not possible to detect isotope incorporation (due to a very low intensity of the corresponding ion peaks). Nonetheless, by analogy to the biosynthesis of rutalexin (4) and considering that both structures contain a thiazinedione ring, we propose that tropalexin B (11) derives from tropalexin A (10) via enzyme mediated hydrolysis followed by $N$-methylation, as summarized in Fig. 9. Although, these results do not allow us to conclude which benzyl glucosinolate and benzylisothiocyanate derivatives are the best substrates of the biosynthetic enzyme(s) catalyzing these reactions, we suggest that 3-hydroxy-4-methoxybenzyl glucosinolate and the corresponding benzylisothiocyanate are better substrates for enzymes involved in the 
biosynthesis of tropalexins $A(\mathbf{1 0})$ and $B(\mathbf{1 1})$ than glucotropaeolin (8) or benzylisothiocyanate (9).

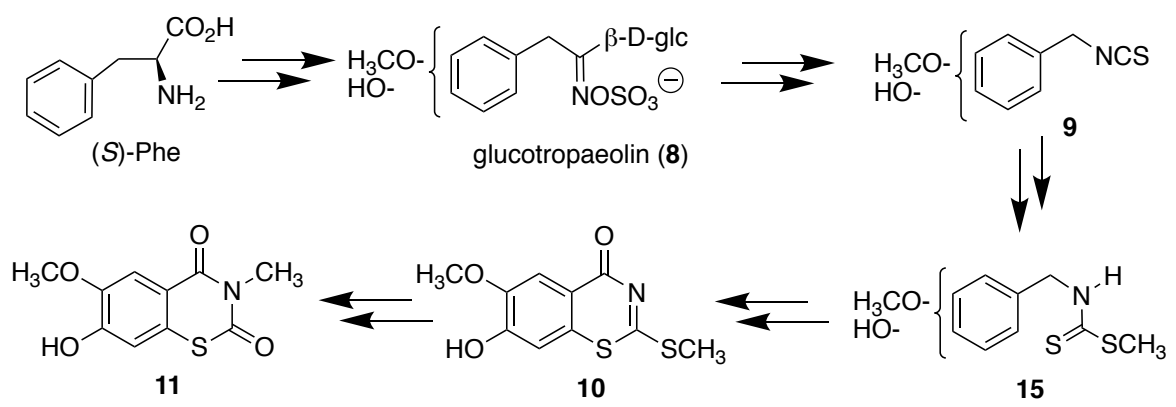

Fig. 9. Proposed biosynthetic pathway of tropalexins A (10) and B (11) from (S)-Phe via the corresponding benzyl glucosinolate(s) e.g., 8 and benzylisothiocyanate(s) e.g., 9 in Tropaeolum majus.

\section{Conclusion}

This work has uncovered the first phytoalexins produced by a Brassicales sp. that do not belong to the Brassicaceae family, i.e., tropalexins $A(10)$ and $B(11)$ are the first non-cruciferous phytoalexins. Although our results indicated that T. majus produces several other elicited metabolites that are likely to function as phytoalexins (Alavi, 2019), due to the amount and stability of those compounds we were unable to purify and fully characterize additional metabolites (Fig. S2). Hence, it is likely that further work will uncover yet unknown phytoalexins produced by $T$. majus that are also derived from hydroxy and/or methoxybenzyl glucosinolates. Furthermore, it is key to recognize that tropalexins $A(10)$ and $B(11)$ are biosynthesized from Phe using a pathway similar to that of well-known cruciferous phytoalexins that derive from Trp (e.g., 2-4) and homoPhe (e.g., 6, 7).

Consequently, these new structures 10 and 11 expand the phytoalexin chemical space and provide metabolic information that shows a great similarity among the defense pathways of Brassicales, suggesting an evolutionary conservation of the corresponding biosynthetic enzymes. In addition, based on the current phylogenetic classification of Brassicales tribes (Guo et al., 2017; Koch and German, 2013) and the chemical structures of cruciferous phytoalexins of species belonging to those tribes (Pedras et al., 2011), we suggest that the primary precursors and intermediates of such pathways are similar within phylogenetically related tribes as for example, 
brassinin (2) and related phytoalexins produced by the tribe Brassiceae, camalexin (14) produced by the tribe Camelineae, nasturlexins 6 and 7 produced by the tribe Cardamineae and wasalexins A and B produced by the closely related tribes Thlaspideae (Thlaspi arvense L.) and Eutremeae (Thellungiella salsuginea (Pall.) O.E. Schulz). Knowledge of the structures and biosynthesis of Brassicales phytoalexins contributes to the design of crops having higher resistance levels to microbial pathogens and abiotic stress (Ahmed and Kovinich, 2020).

\section{Experimental}

\subsection{General}

All solvents were HPLC grade and used as such; unless otherwise noted, materials were obtained from commercial suppliers and used without further purification. Flash column chromatography (FCC) was carried out using silica gel grade 60 , mesh size $230-400 \AA$ or RP $\mathrm{C}_{18}$ prepscale bulk packing $275 \AA$ (J.T. Baker, NJ, USA). Organic extracts were dried over $\mathrm{Na}_{2} \mathrm{SO}_{4}$ and solvents were removed using a rotary evaporator.

NMR spectra were recorded on Bruker Avance spectrometers. For ${ }^{1} \mathrm{H}$ NMR (500 or 600 $\mathrm{MHz}$ ) and ${ }^{13} \mathrm{C}$ NMR (125.8 or $150.9 \mathrm{MHz}$ ) spectra, the chemical shifts $(\delta)$ are reported in parts per million (ppm) relative to TMS. MS data [high resolution (HR) were obtained on a Jeol AccuToF GCv 4G mass spectrometer [field desorption (FD)] or on a Qstar XL MS/MS System (ESI) by direct insertion.

\subsection{HPLC analyses}

HPLC-DAD analysis was carried out with Agilent 1100 and 1200 series systems equipped with quaternary pumps, autosamplers, diode array detectors (DAD, wavelength range 190-600 $\mathrm{nm}$, bandwidth $4 \mathrm{~nm}$ ), degasser and a Zorbax Eclipse XDB-C18 column (5 $\mu \mathrm{m}$ particle size silica, $150 \times 4.6 \mathrm{~mm}$ I.D.), equipped with an in-line filter. Method A: mobile phase $\mathrm{H}_{2} \mathrm{O}-\mathrm{CH}_{3} \mathrm{CN}$ from $75: 25$ to $25: 75$, linear gradient for $35 \mathrm{~min}$, and a flow rate of $1.0 \mathrm{~mL} / \mathrm{min}$. Detection and quantification of phytoalexins was carried out using method $A$ and calibration curves built for each purified metabolite $\left(r^{2} \geq 0.993\right)$.

HPLC-DAD-ESI-MS analysis was carried out with an Agilent 1100 series HPLC system equipped with an autosampler, binary pump, degasser, and a diode array detector connected 
directly to a mass detector (Agilent G2440A MSD-Trap-XCT ion trap mass spectrometer) with an electrospray ionization (ESI) source. Chromatographic separations were carried out at room temperature using an Eclipse XDB-C-18 column ( $5 \mu \mathrm{m}$ particle size silica, $150 \mathrm{~mm} \times 4.6 \mathrm{~mm}$ I.D.). Method B: mobile phase $\mathrm{H}_{2} \mathrm{O}$ (with $0.2 \% \mathrm{HCO}_{2} \mathrm{H}$ ) - $\mathrm{CH}_{3} \mathrm{CN}$ (with $0.2 \% \mathrm{HCO}_{2} \mathrm{H}$ ) from $75: 25$ to $25: 75$ linear gradient for $25 \mathrm{~min}$ and a flow rate of $1.0 \mathrm{~mL} / \mathrm{min}$. Data acquisition was carried out in positive and negative polarity modes in a single LC run, and data processing carried out with Agilent Chemstation Software.

FTIR spectra were obtained using a Bruker Tensor 27, resolution $2 \mathrm{~cm}^{-1}$; samples were prepared as a film on a $\mathrm{KBr}$ disk or pellet using dry $\mathrm{KBr}$ (IR grade).

4.3 Plants, elicitation conditions and time-course analyses

Seeds of $T$. majus were obtained from Cornucopia seeds (http://www.cornucopiaseeds.com.au). The seeds were planted in a perlite and nutrient free LG3 soil (Sun Gro Horticulture Canada) in small pots (each pot $15 \mathrm{~cm}$-diameter) in a growth chamber (16 h of light/8 $\mathrm{h}$ of dark). For elicitation of phytoalexins, 4-week-old plants were sprayed with an aq. $\mathrm{CuCl}_{2}$ solution $(10 \mathrm{mM})$ and plants were kept in the growth chamber for several days; leaves (ca. $2.0 \mathrm{~g}$ fresh weight per sample) were excised 24,72 and $120 \mathrm{~h}$ post elicitation, were frozen in liq. $\mathrm{N}_{2}$, ground and the resulting leaf materials were individually extracted with $\mathrm{MeOH}(10 \mathrm{~mL})$. The extracts were filtered, the filtrates were concentrated, rinsed with $\mathrm{CH}_{2} \mathrm{Cl}_{2}$ and the $\mathrm{CH}_{2} \mathrm{Cl}_{2}$ rinses were concentrated, dissolved in $\mathrm{CH}_{3} \mathrm{CN}-\mathrm{MeOH}$ (1:1) and analyzed by HPLC-DAD using method $A$ and by HPLC-DAD-ESI-MS using method $B$.

\subsection{Isolation and characterization of elicited metabolites}

For isolation of tropalexins $\mathrm{A}(10)$ and $\mathrm{B}(11), \mathrm{CH}_{2} \mathrm{Cl}_{2}$ extracts of elicited leaves collected from 36 elicited plants incubated for $120 \mathrm{~h}$ were used. Leaves (fresh weight ca. $600 \mathrm{~g}$ ) were extracted with $\mathrm{CH}_{2} \mathrm{Cl}_{2}$, the extracts were combined and concentrated, and compounds isolated as summarized in Fig. 10. 


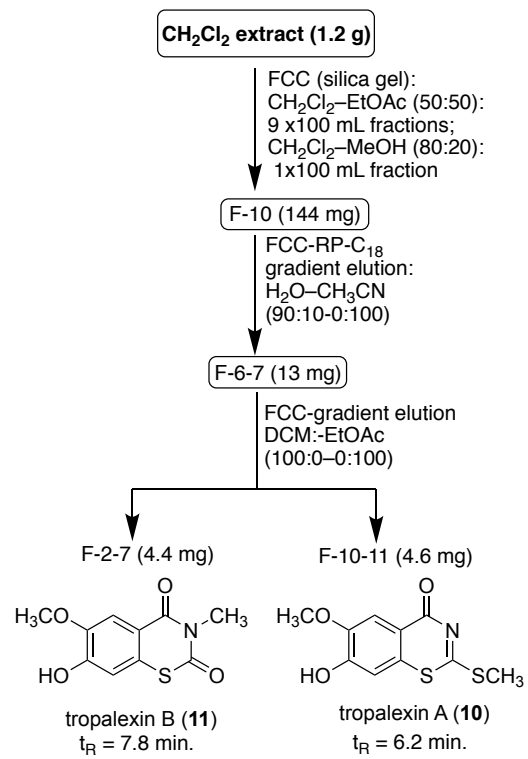

Fig. 10. Isolation of tropalexins $A(\mathbf{1 0})$ and $B(\mathbf{1 0})$ from leaf extracts of elicited plants.

Tropalexin A (10). HPLC $t_{R}=6.2 \mathrm{~min}$, method A. ${ }^{1} \mathrm{H}$ and ${ }^{13} \mathrm{C}$ NMR: Table 1. HR-ESI-MS $\mathrm{m} / \mathrm{z}$ (\%): calc. for $\mathrm{C}_{10} \mathrm{H}_{10} \mathrm{NO}_{3} \mathrm{~S}_{2}: 256.0096$, found 256.0104 (100\%) $\left([\mathrm{M}+\mathrm{H}]^{+}\right)$. UV (HPLC, $\mathrm{CH}_{3} \mathrm{CN}-$ $\left.\mathrm{H}_{2} \mathrm{O}\right) \lambda_{\max }(\mathrm{nm}): 230,255,280,350$. FTIR (KBr) $\nu_{\max }: 3071,2920,2851,1629,1575 \mathrm{~cm}^{-1}$.

Tropalexin B (11). HPLC $t_{R}=7.8$ min, method A. ${ }^{1} \mathrm{H}$ and ${ }^{13} \mathrm{C}$ NMR: Table 1. HR-ESI-MS $\mathrm{m} / \mathrm{z}$ (\%): calc. for $\mathrm{C}_{10} \mathrm{H}_{8} \mathrm{NO}_{4} \mathrm{~S}: 238.0179$, found 238.0178 (100) ([M-H] $\left.]^{-}\right)$. UV (HPLC, $\left.\mathrm{CH}_{3} \mathrm{CN}-\mathrm{H}_{2} \mathrm{O}\right)$ $\lambda_{\max }(\mathrm{nm}): 245,325 . \mathrm{FTIR}(\mathrm{KBr}) v_{\max }: 3449,2921,2850,1662,1632 \mathrm{~cm}^{-1}$.

\subsection{Antifungal bioassays}

Spores of $A$. brassicicola isolate UAMH 7474 and L. maculans isolate UAMH 9410, were obtained from the University of Alberta Micro fungus Collection and Herbarium; spores of Sclerotinia sclerotiorum clone \#33, were obtained from the AAFC Saskatoon Research Center. The antifungal activity of each compound against the three fungal species was determined using a standard radial growth inhibition assay as previously described (12-well plates containing PDA and DMSO solutions of each compound at $0.50,0.25$, and $0.10 \mathrm{mM}$; control plates contained $1 \%$ DMSO in PDA) (Pedras and To, 2015). In brief, mycelial plugs (2 $\mathrm{mm}$ ) cut from the edges of actively growing plates were placed inverted onto 12-well plates containing compounds in DMSO mixed into PDA. Plates were allowed to grow under constant light/dark at $23 \pm 1^{\circ} \mathrm{C}$ for $18-36 \mathrm{~h}$; the diameter of the mycelial mat was measured and compared to control mycelia grown on plates 
containing DMSO. The phytoalexin camalexin (14), synthesized as previously reported (Pedras and Abdoli, 2018) was used as positive control.

4.6 Administration of isotopically labelled compounds 9 a and 15a and extraction of phytoalexins

For feeding experiments, four-week-old plants were sprayed with an aq. $\mathrm{CuCl}_{2}$ solution (10 $\mathrm{mM}$ ) and incubated under fluorescent light for 24 h. After 24 h, 2-5 leaves were cut and petioles were immediately immersed in tubes containing an aqueous solution of the labelled compound $\left(\mathrm{H}_{2} \mathrm{O}-\mathrm{MeOH}, 9: 1, \mathrm{v} / \mathrm{v}\right)$ and incubated up to $72 \mathrm{~h}$ under continuous fluorescent light. Following the uptake of each solution, the tubes were refilled with $\mathrm{H}_{2} \mathrm{O}$. After incubation times $(24,48,72 \mathrm{~h})$ the leaves were frozen in liquid nitrogen and extracted with $\mathrm{MeOH}$ (shaking, 60 min). The $\mathrm{MeOH}$ extract was filtered, concentrated and rinsed with $\mathrm{CH}_{2} \mathrm{Cl}_{2}$. The $\mathrm{CH}_{2} \mathrm{Cl}_{2}$ extract was concentrated and analyzed by HPLC-DAD and HPLC-DAD-ESI-MS. Elicited leaves fed with non-labelled compounds and non-elicited leaves incubated in $\mathrm{H}_{2} \mathrm{O}-\mathrm{MeOH}(9: 1)$ were used as controls. All experiments were conducted in triplicate and repeated at least once.

\section{Acknowledgements}

Financial support for the authors' work was obtained from the Natural Sciences and Engineering Research Council of Canada (Discovery Grant to M.S.C.P.), the Canada Research Chairs program, Canada Foundation for Innovation, the Saskatchewan Government, and the University of Saskatchewan (graduate assistantships to MA). We acknowledge the technical assistance of K. Thoms (MS), Saskatchewan Structural Sciences Centre and Department of Chemistry. 


\section{References}

Alavi, M. 2019. Elicited metabolites from Brassicaceae species and Tropaeolum majus: isolation, structure determination and antifungal activity. Ph.D. Thesis, University of Saskatchewan, SK.

Ahmed, S., Kovinich, N. 2020. Regulation of phytoalexin biosynthesis for agriculture and human health. https://doi.org/10.1007/s11101-020-09691-8.

Blazevic, I., Montaut, S., Burcul, F., Olsen, C. E., Burow, M., Rollin, P., Agerbirk, N. 2020. Glucosinolate structural diversity, identification, chemical synthesis and metabolism in plants. Phytochemistry 169, 112100.

Bailey, J. A., Mansfield, J. W. Phytoalexins, Blackie and Son, Glasgow, U. K., 1982, 334 pp.

Bazylko, A., Granica, S., Filipek, A.; Piwowarski, J., Stefanska, J., Osinska, E., Kiss, A. K. 2013. Comparison of antioxidant, anti-inflammatory, antimicrobial activity and chemical composition of aqueous and hydroethanolic extracts of the herb of Tropaeolum majus L. Ind. Crops Prod. 50, 88-94.

Du, L., Halkier, B. A. 1996. Isolation of a Microsomal Enzyme System Involved in Glucosinolate Biosynthesis from Seedlings of Tropaeolum majus L., Plant Physiol. 111, 831-837.

Edger, P. P., Hall, J. C., Harkess, A., Tang, M., Coombs, J., Mohammadin, S., Schranz, M. E. 2018. Brassicales phylogeny inferred from 72 plastid genes: A reanalysis of the phylogenetic localization of two paleopolyploid events and origin of novel chemical defenses. Am. J. Bot. 105, 463-469.

Gasparotto, A., Jr., Gasparotto, F. M.; Boffo, M. A., Lourenco, E. L. B., Stefanello, M. E. A., Salvador, M. J., da Silva-Santos, J. E., Marques, M. C. A., Kassuya, C. A. L. 2011. Diuretic and potassium-sparing effect of isoquercitrin - An active flavonoid of Tropaeolum majus $\mathrm{L}$. J. Ethnopharmacol. 134, 210-215.

Guo, X., Liu, J., Hao, G., Zhang, L., Mao, K., Wang, X., Zhang, D., Ma, T., Hu, Q., Al-Shehbaz, I. A., Koch, M. A. 2017. Plastome phylogeny and early diversification of Brassicaceae. BMC Genomics 18, 176.

Jakubczyk, K., Janda, K., Watychowicz, K., Lukasiak, J., Wolska, J. 2018. Garden nasturtium (Tropaeolum majus L.) - a source of mineral elements and bioactive compounds. Rocz. Panstw. Zakl. Hig. 69, 119-126.

Koch, M. A., German, D. A. 2013. Taxonomy and systematics are key to biological information: Arabidopsis, Eutrema (Thellungiella), Noccaea and Schrenkiella (Brassicaceae) as examples. Front. Plant Sci. 4:267. doi: 10.3389/fpls.2013.00267

Kúc, J. 1995. Phytoalexins, stress metabolism, and disease resistance in plants, Annu. Rev. Phytopathol. 33, 275-297.

Liu, C-M., Li, B., Shen, Y.-S., Zhang W.-D. 2010. Heterocyclic compounds and aromatic diglycosides from Bretschneidera sinensis. J. Nat. Prod. 73, 1582-1585.

Montaut, S., Zhang, W.-D., Nuzillard, J.-M., De Nicola, G. R., Rollin, P. 2015. Glucosinolate diversity in Bretschneidera sinensis of Chinese origin. J. Nat. Prod. 78, 2001-2006. 
Pedras, M. S. C., Abdoli, A. 2017. Pathogen inactivation of cruciferous phytoalexins: detoxification reactions, enzymes and inhibitors. RSC Adv. 7, 23633-23646.

Pedras, M. S. C., Abdoli, A. 2018. Methoxycamalexins and related compounds: Syntheses, antifungal activity and inhibition of brassinin oxidase. Bioorg. Med. Chem. 26, 4461-4469.

Pedras, M. S. C., Alavi, A., To, Q. H., 2015. Expanding the nasturlexin family: nasturlexins C and $D$ and their sulfoxides are phytoalexins from the crucifers Barbarea vulgaris and $B$. verna. Phytochemistry 118, 131-138.

Pedras, M. S. C., To, Q. H., 2015. Non-indolyl cruciferous phytoalexins: Nasturlexins and tridentatols, a striking convergent evolution of defenses in terrestrial plants and marine animals? Phytochemistry 113, 57-63.

Pedras, M.S.C., To, Q. H., 2016. Unveiling the first indole-fused thiazepine: structure, synthesis and biosynthesis of cyclonasturlexin, a remarkable cruciferous phytoalexin. Chem. Commun. 52, 5880-5883.

Pedras, M. S. C., To, Q. H. 2018a. Synthesis of stable isotope-labeled nasturlexins and potential precursors to probe biosynthetic pathways of cruciferous phytoalexins. J. Label. Compd. Radiopharm. 61, 94-106.

Pedras, M. S. C., To, Q. H. 2018b. Interrogation of biosynthetic pathways of the cruciferous phytoalexins nasturlexins with isotopically labelled compounds. Org. Biomol. Chem. 2018, 16, 3625-3638.

Pedras, M. S. C., Yaya, E.E., Glawischnig, E., 2011. The phytoalexins from cultivated and wild crucifers: chemistry and biology. Nat. Prod. Rep. 28, 1381-1405.

Takasugi, M., Katsui, N., Shirata, A. 1986. Isolation of three novel sulphur-containing phytoalexins from the Chinese cabbage Brassica campestris L. ssp. pekinensis (Cruciferae) J. Chem. Soc., Chem. Comm. 1077.

VanEtten, H.D., Mansfield, J.W., Bailey, J.A., Farmer, E.E., 1994. Two classes of plant antibiotics: "Phytoalexins" versus "phytoanticipins." Plant Cell 6, 1191-1192. 


\section{Supporting Information}

1. Flow chart of plant elicitation and time-course analyses of metabolites

The $\mathrm{CH}_{2} \mathrm{Cl}_{2}$ extracts were analyzed by HPLC-DAD and HPLC-DAD-ESI-MS (Fig. S2). Only the peak at ca. $22.7 \mathrm{~min}$ (fig. S2) corresponded to a known metabolite available in our UV spectral and MS libraries (benzylisothiocyanate (9)).

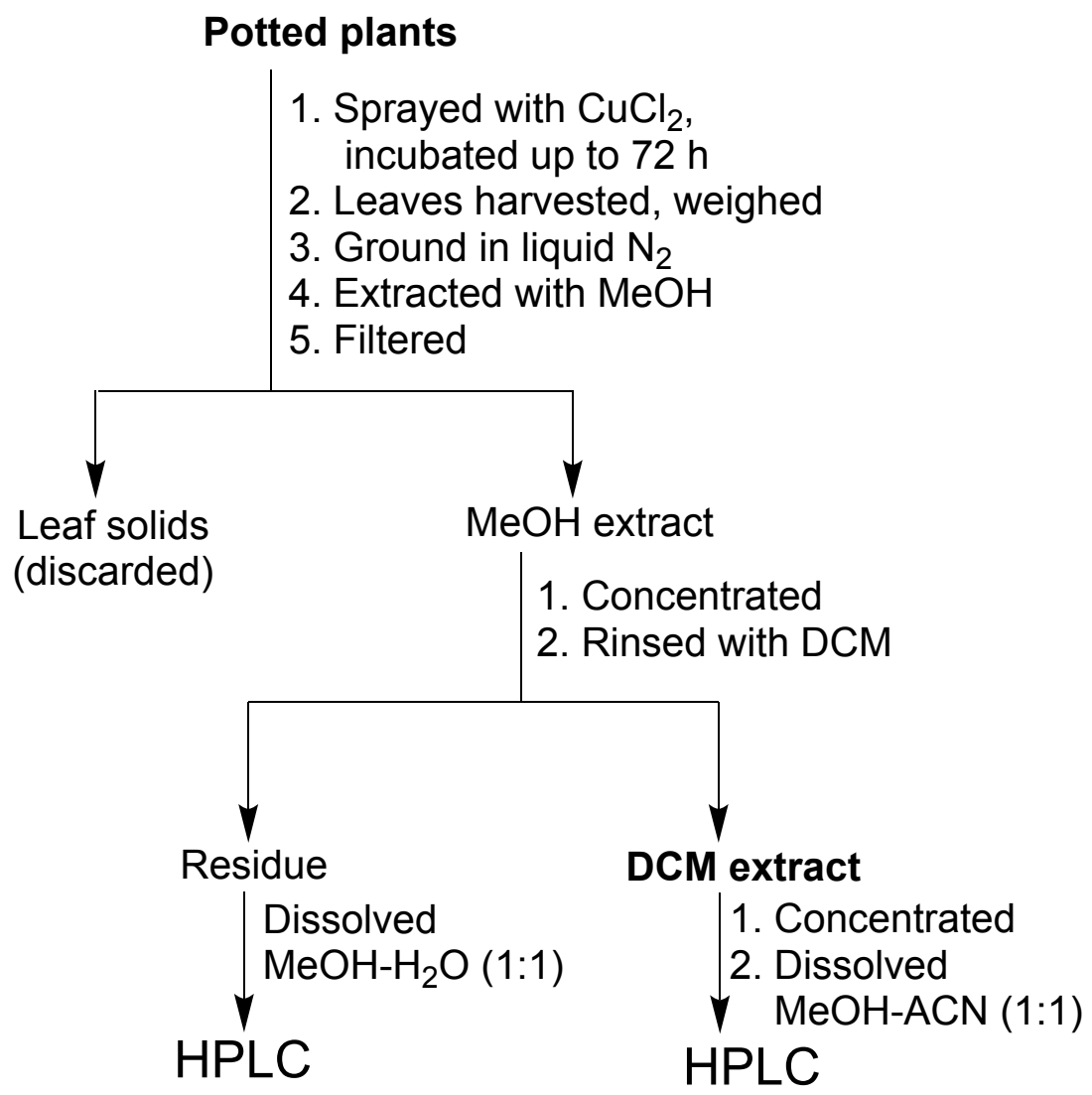

Fig. S1. General flow chart for elicitation and time-course analysis of plant metabolites. 


\section{HPLC-DAD chromatograms of leaf extracts}

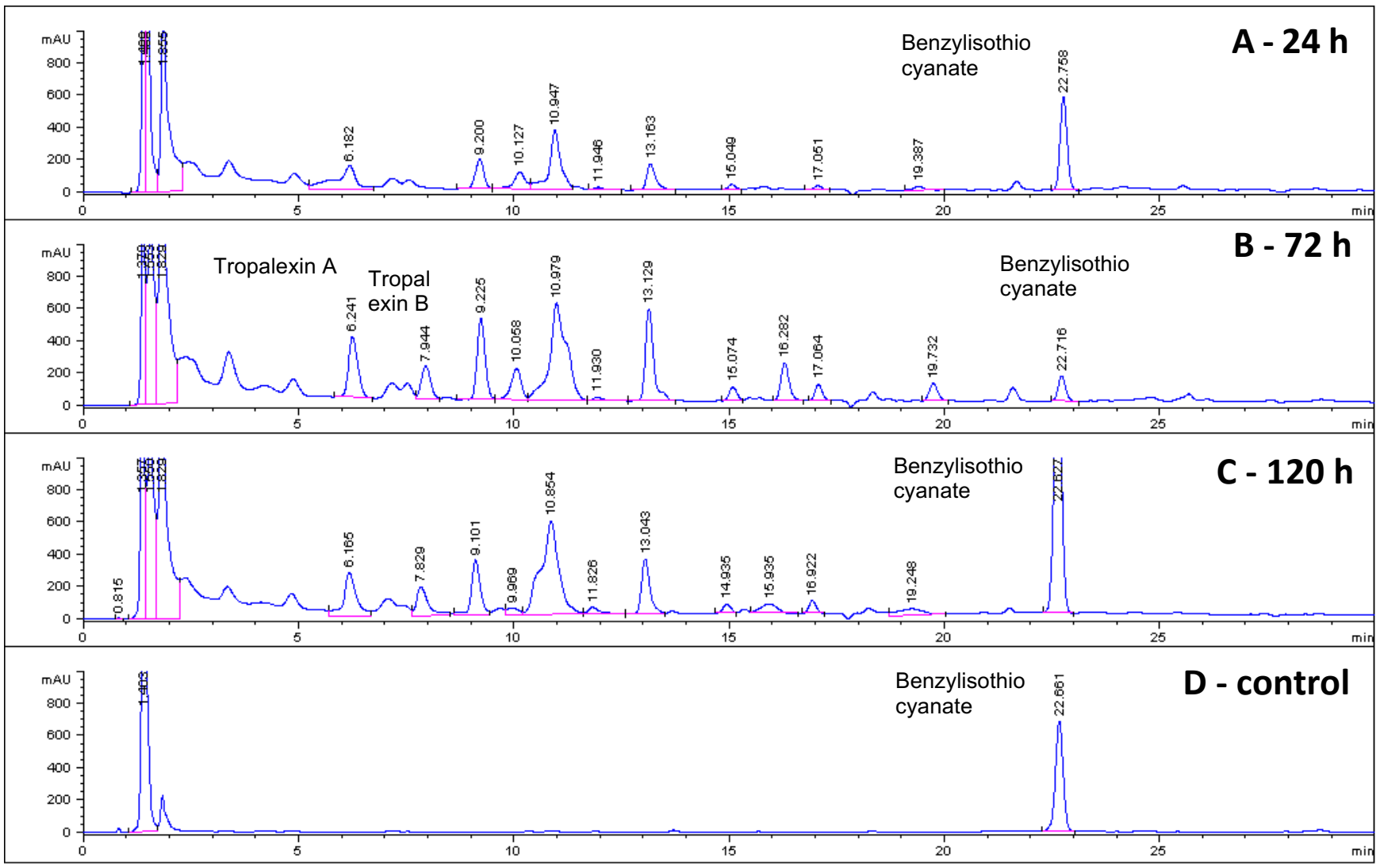

Fig. S2. HPLC-DAD chromatograms (method A, $220 \mathrm{~nm}$ ) of extracts of elicited leaves of Tropaeolum majus: A, $24 \mathrm{~h}$ post-elicitation; B, $72 \mathrm{~h}$ post-elicitation; C, $120 \mathrm{~h}$ post-elicitation; D extracts of non-elicited leaves (control). Metabolites: $t_{R}=6.2 \mathrm{~min}$, tropalexin $A(10) ; t_{R}=7.8 \mathrm{~min}$, tropalexin $B(11) ; t_{R}=22.7$ min, benzylisothiocyanate (9). 
3. Synthesis and characterization of isotopically labelled compounds

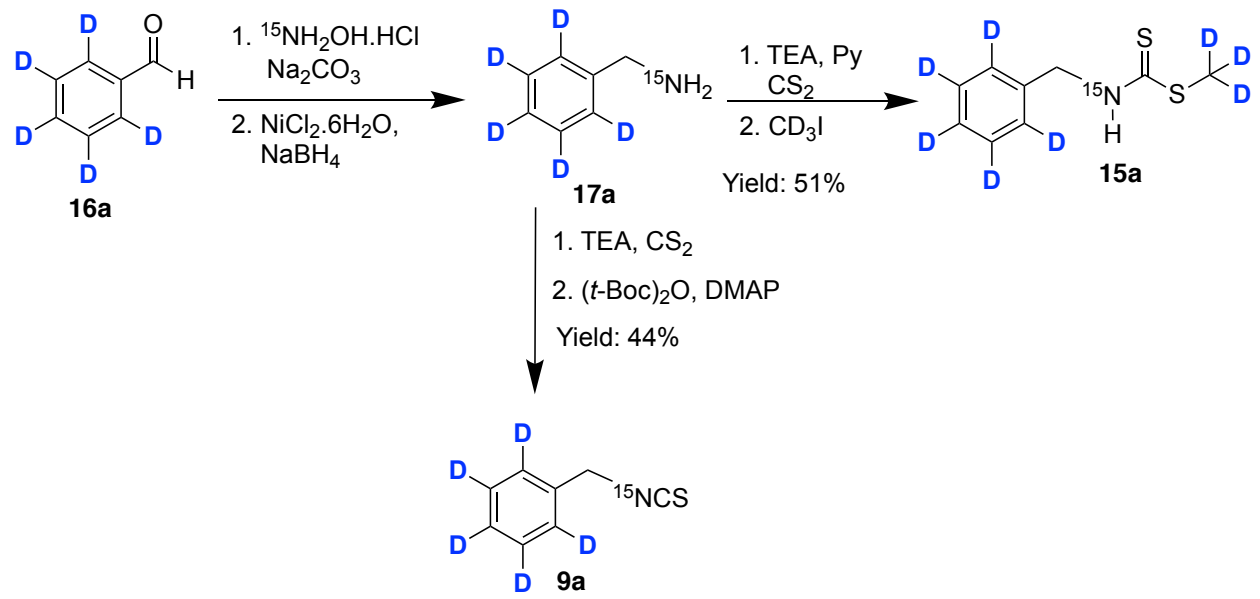

\section{$3.1\left[2,3,4,5,6-{ }^{2} \mathrm{H}_{5},{ }^{15} \mathrm{~N}\right] \mathrm{benzy}$ lisothiocyanate (9a)}

$\mathrm{CS}_{2}(217 \mu \mathrm{L}, 3.6 \mathrm{mmol})$ and $\mathrm{Et}_{3} \mathrm{~N}(60 \mu \mathrm{L}, 0.43 \mathrm{mmol})$ were added to [2,3,4,5,6${ }^{2} \mathrm{H}_{5},{ }^{15} \mathrm{~N}$ ]benzylamine (17a) $(41 \mathrm{mg}, 0.36 \mathrm{mmol}$, in $\mathrm{EtOH}, 0.5 \mathrm{~mL})$. The reaction mixture was stirred at room temperature for $30 \mathrm{~min}$ and then cooled on an ice bath. ( $t-\mathrm{Boc})_{2} \mathrm{O}(93 \mathrm{mg}, 0.43 \mathrm{mmol}$ in $\mathrm{EtOH}, 0.5 \mathrm{~mL}$ ) was added dropwise, followed by DMAP (ca. $2 \mathrm{mg}, 0.018 \mathrm{mmol}$ ). The reaction mixture was stirred at $0{ }^{\circ} \mathrm{C}$ for $5 \mathrm{~min}$, then at room temperature for a further $10 \mathrm{~min}$, diluted with water and extracted with $\mathrm{CH}_{2} \mathrm{Cl}_{2}$. The organic extract was dried over $\mathrm{Na}_{2} \mathrm{SO}_{4}$, concentrated and separated by FCC (silica gel, $\mathrm{CH}_{2} \mathrm{Cl}_{2}$-hexane, 10:90) to yield [2,3,4,5,6${ }^{2} \mathrm{H}_{5},{ }^{15} \mathrm{~N}$ ]benzylisothiocyanate (9a) (25 mg, $0.16 \mathrm{mmol}$ ) in $44 \%$ (from aldehyde 16a).

$\left[2,3,4,5,6-{ }^{2} H_{5},{ }^{15} \mathrm{~N}\right]$ Benzylisothiocyanate (9a). HPLC $t_{R}=23.4$ min (method A). UV (HPLC, $\left.\mathrm{CH}_{3} \mathrm{CN}-\mathrm{H}_{2} \mathrm{O}\right) \lambda_{\max }(\mathrm{nm}): 240 .{ }^{1} \mathrm{H}$ NMR $\left(500 \mathrm{MHz}, \mathrm{CDCl}_{3}\right): \delta 4.73(2 \mathrm{H}, \mathrm{d}, J=3 \mathrm{~Hz})$.

\subsection{Synthesis of $\left[{ }^{2} \mathrm{H}_{3} \mathrm{CS}\right]$ methyl $\left[2,3,4,5,6-{ }^{2} \mathrm{H}_{5},{ }^{15} \mathrm{~N}\right]$ benzyldithiocarbamate (15a).}

${ }^{15} \mathrm{NH}_{2} \mathrm{OH} . \mathrm{HCl}(127 \mathrm{mg}, 1.80 \mathrm{mmol})$ and $\mathrm{Na}_{2} \mathrm{CO}_{3}(114 \mathrm{mg}, 1.08 \mathrm{mmol})$ dissolved in water $(1.5 \mathrm{~mL})$ were added to commercially available $\left[2,3,4,5,6-{ }^{2} \mathrm{H}_{5}\right]$ benzaldehyde (16a) $(100 \mathrm{mg}, 0.90$ $\mathrm{mmol}$, in $\mathrm{EtOH}, 3,5 \mathrm{~mL}$ ) at rt. The reaction mixture was stirred at $80^{\circ} \mathrm{C}$ for $30 \mathrm{~min}$, diluted with water, extracted with EtOAc and the organic extract dried over $\mathrm{Na}_{2} \mathrm{SO}_{4}$ and concentrated. $\mathrm{NaBH}_{4}$ (157 mg, $4.15 \mathrm{mmol}$ ) was added in portions to a mixture of the crude oxime (106 mg, $0.83 \mathrm{mmol}$ ) and $\mathrm{NiCl}_{2} .6 \mathrm{H}_{2} \mathrm{O}(235 \mathrm{mg}, 0.99 \mathrm{mmol})$ in $\mathrm{MeOH}(3.0 \mathrm{~mL})$ at $0{ }^{\circ} \mathrm{C}$ under stirring. After $10 \mathrm{~min}$, the reaction mixture was filtered through a sintered-glass funnel, the filtrate was diluted with water 
and extracted with $\mathrm{CHCl}_{3}$. The organic extract was dried over $\mathrm{Na}_{2} \mathrm{SO}_{4}$ and concentrated to yield the crude amine $17 \mathrm{a}$. $\mathrm{CS}_{2}(43 \mu \mathrm{L}, 0.72 \mathrm{mmol})$ was added to a solution of crude amine $(41 \mathrm{mg}$, $0.36 \mathrm{mmol})$ and $\mathrm{Et}_{3} \mathrm{~N}(102 \mu \mathrm{L}, 0.72 \mathrm{mmol})$ in pyridine $(1.5 \mathrm{~mL})$ at $0{ }^{\circ} \mathrm{C}$. After stirring for $15 \mathrm{~min}$ at room temperature, $\mathrm{C}^{2} \mathrm{H}_{3} \mathrm{l}(45 \mu \mathrm{L}, 0.72 \mathrm{mmol})$ was added and the reaction mixture was stirred for an additional $15 \mathrm{~min}$. The mixture was diluted with toluene, concentrated and separated by FCC (silica gel, EtOAc-hexane, 10:90) to yield $\left[{ }^{2} \mathrm{H}_{3} \mathrm{CS}\right]$ methyl $\left[2,3,4,5,6-{ }^{2} \mathrm{H}_{5},{ }^{15} \mathrm{~N}\right]$ benzyldithiocarbamate (15a) $(47 \mathrm{mg}, 0.23 \mathrm{mmol})$ in $51 \%$ (from aldehyde 16a).

[ ${ }^{2} \mathrm{H}_{3} \mathrm{CS}$ ]methyl $\left[2,3,4,5,6-{ }^{2} \mathrm{H}_{5},{ }^{15} \mathrm{~N}\right]$ benzyldithiocarbamate (15a). HPLC $t_{\mathrm{R}}=17.6 \mathrm{~min}$ (method A). ${ }^{1} \mathrm{H}$ NMR $\left(500 \mathrm{MHz}, \mathrm{CDCl}_{3}\right): \delta 6.97(1 \mathrm{H}, \mathrm{dt}, J=90,5.0 \mathrm{~Hz}), 4.93(2 \mathrm{H}, \mathrm{d}, J=5.0 \mathrm{~Hz})$, and a rotamer at 7.75 (dt), 4.64 (brs). HR-ESI-MS m/z (\%): calc. for $\mathrm{C}_{9} \mathrm{H}_{4}{ }^{2} \mathrm{H}_{8}{ }^{15} \mathrm{NS}_{2}: 207.0878$, found 207.0876 (100). UV (HPLC, $\mathrm{CH}_{3} \mathrm{CN}-\mathrm{H}_{2} \mathrm{O}$ ) $\lambda_{\max }(\mathrm{nm}): 250,270$. 


\section{Tropalexin A (10)}<smiles></smiles>
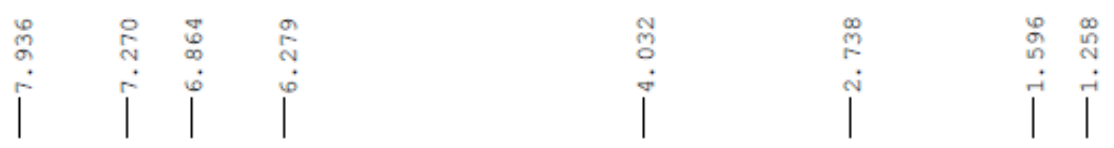

${ }^{1} \mathrm{H} \mathrm{NMR}\left(500 \mathrm{MHz}, \mathrm{CDCl}_{3}\right.$ )

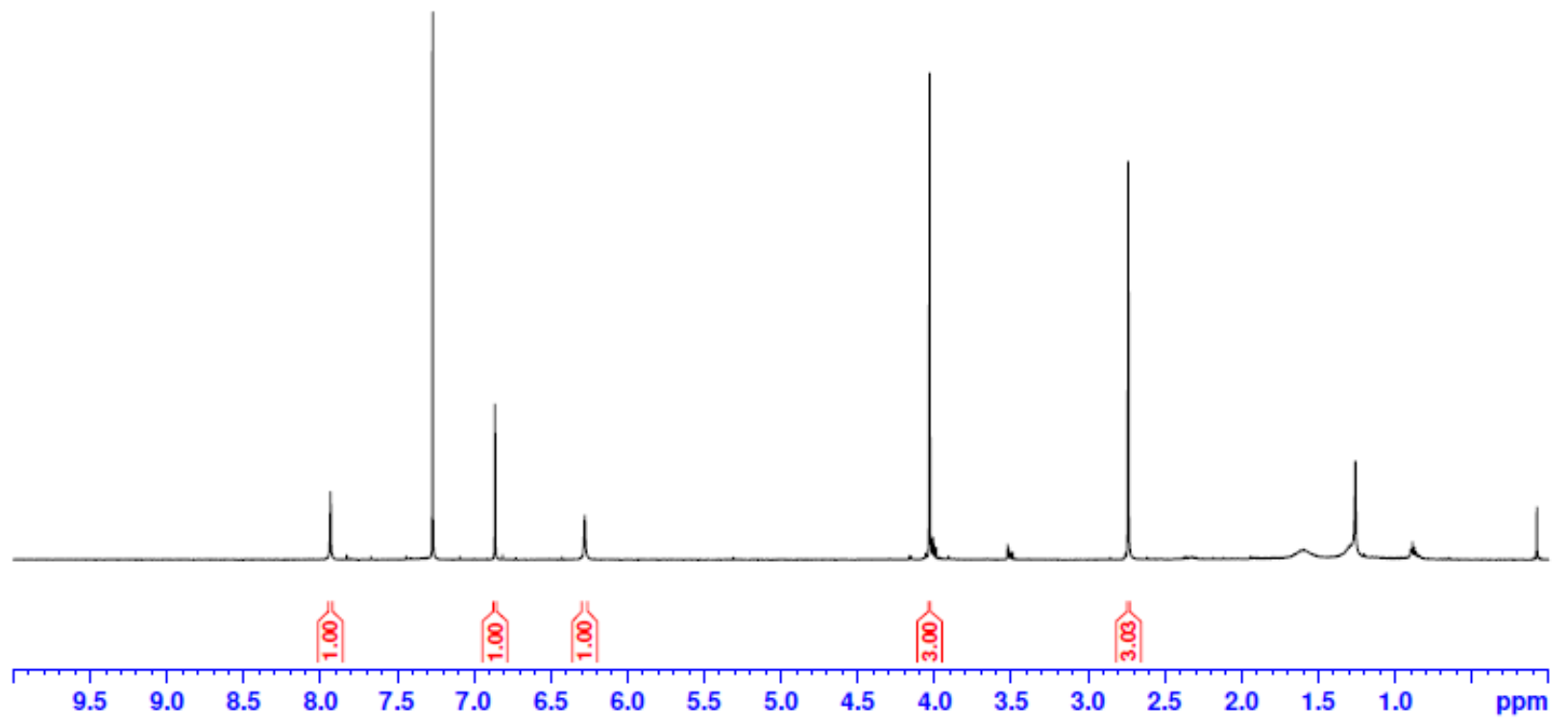


${ }^{13} \mathrm{C}$ NMR $\left(125 \mathrm{MHz}, \mathrm{CDCl}_{3}\right)$
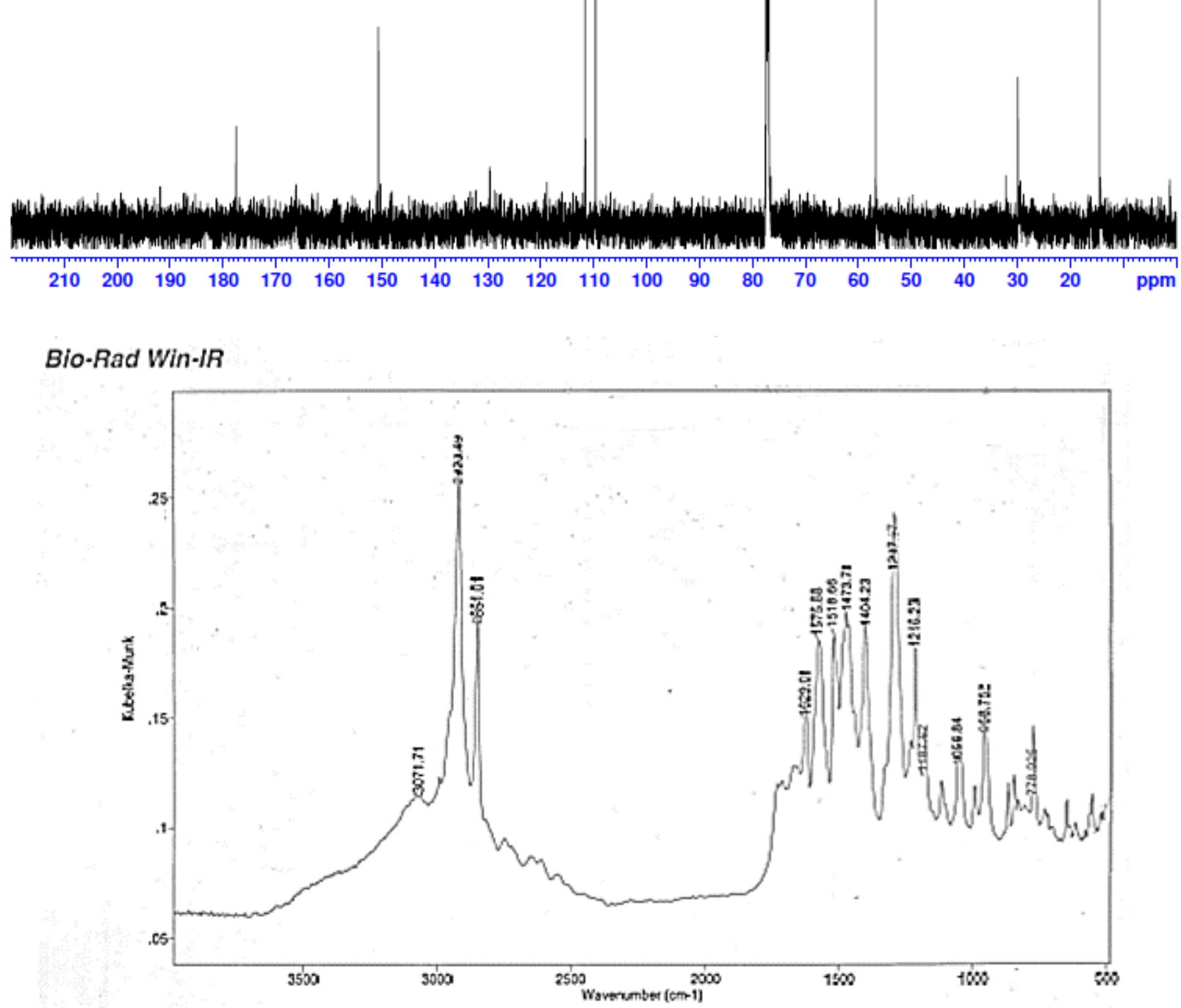


\section{Tropalexin B (11)}
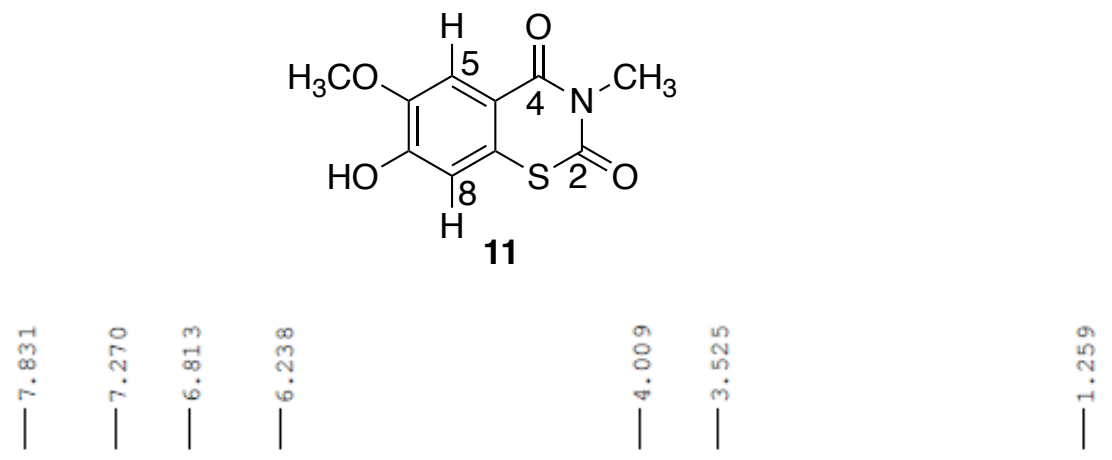

${ }^{1} \mathrm{H}$ NMR (500 MHz, $\mathrm{CDCl}_{3}$ )

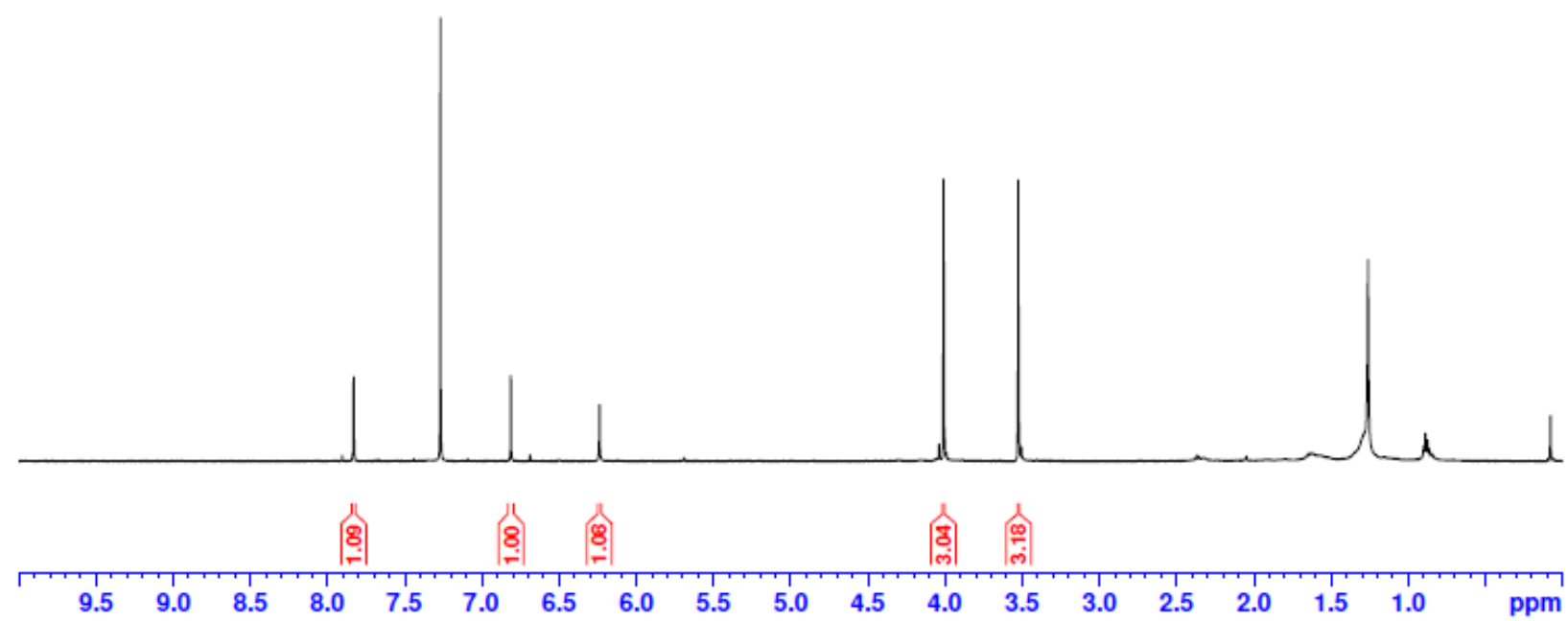


${ }^{13} \mathrm{C} \mathrm{NMR}\left(125 \mathrm{MHz}, \mathrm{CDCl}_{3}\right)$

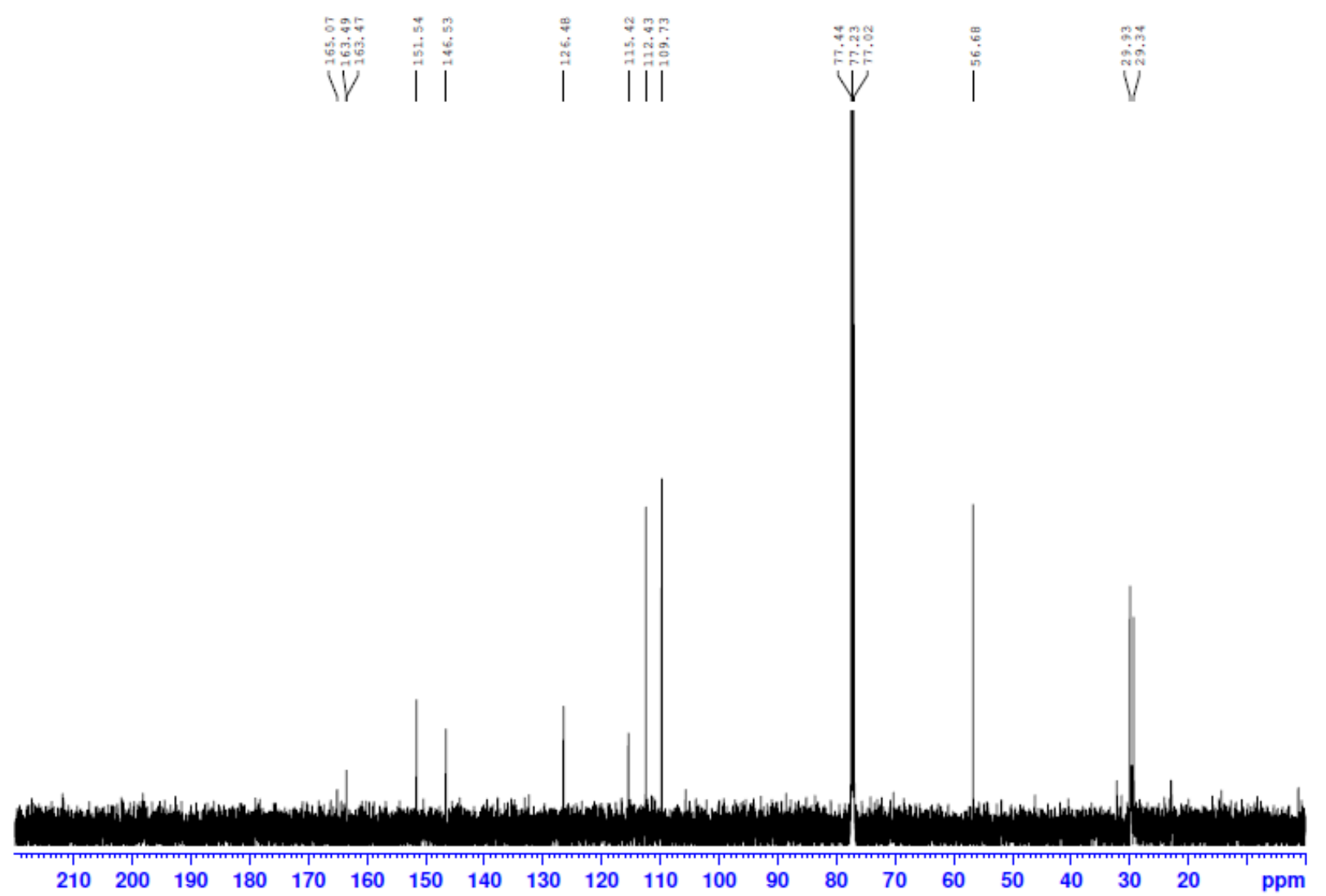

\section{Bio-Rad Win-IR}

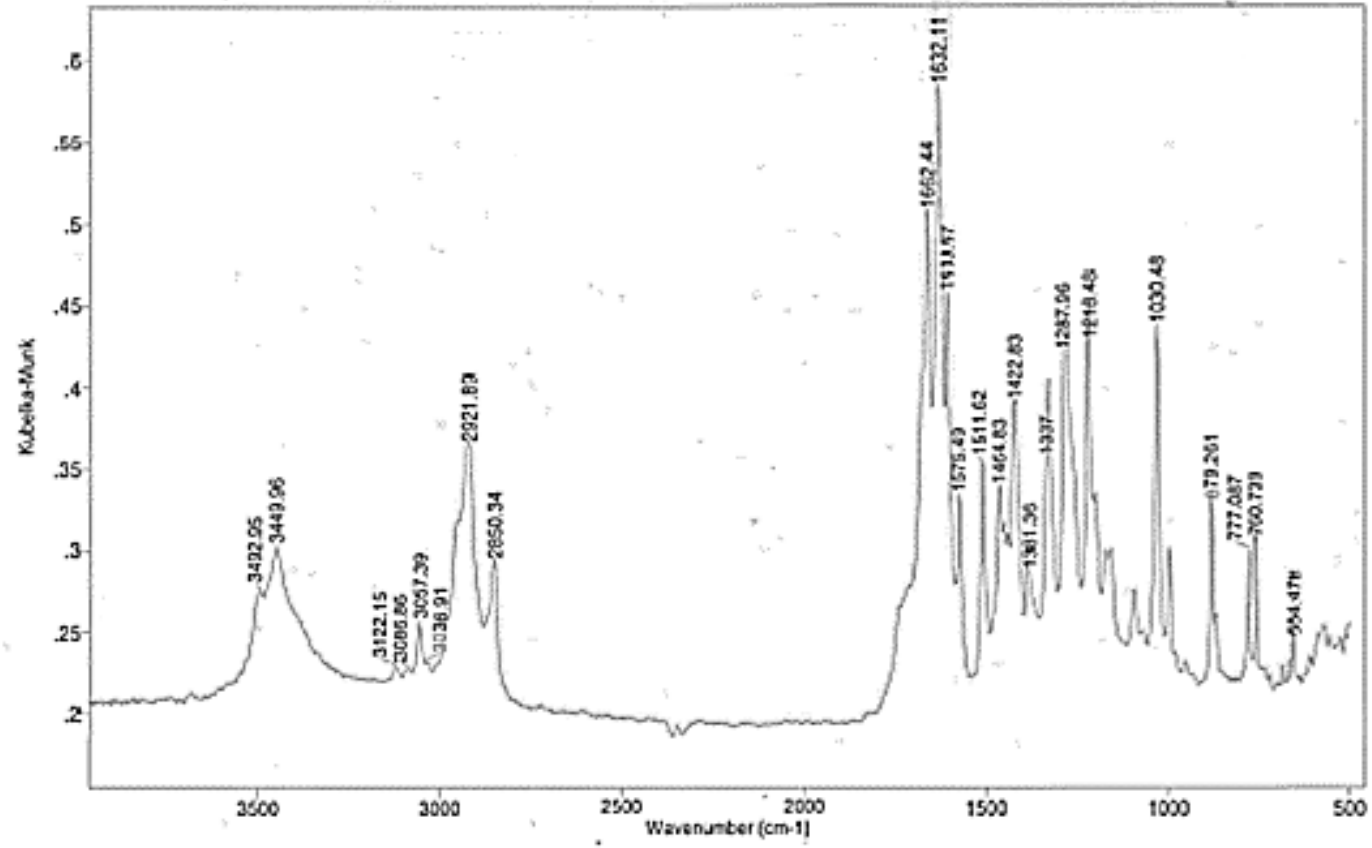




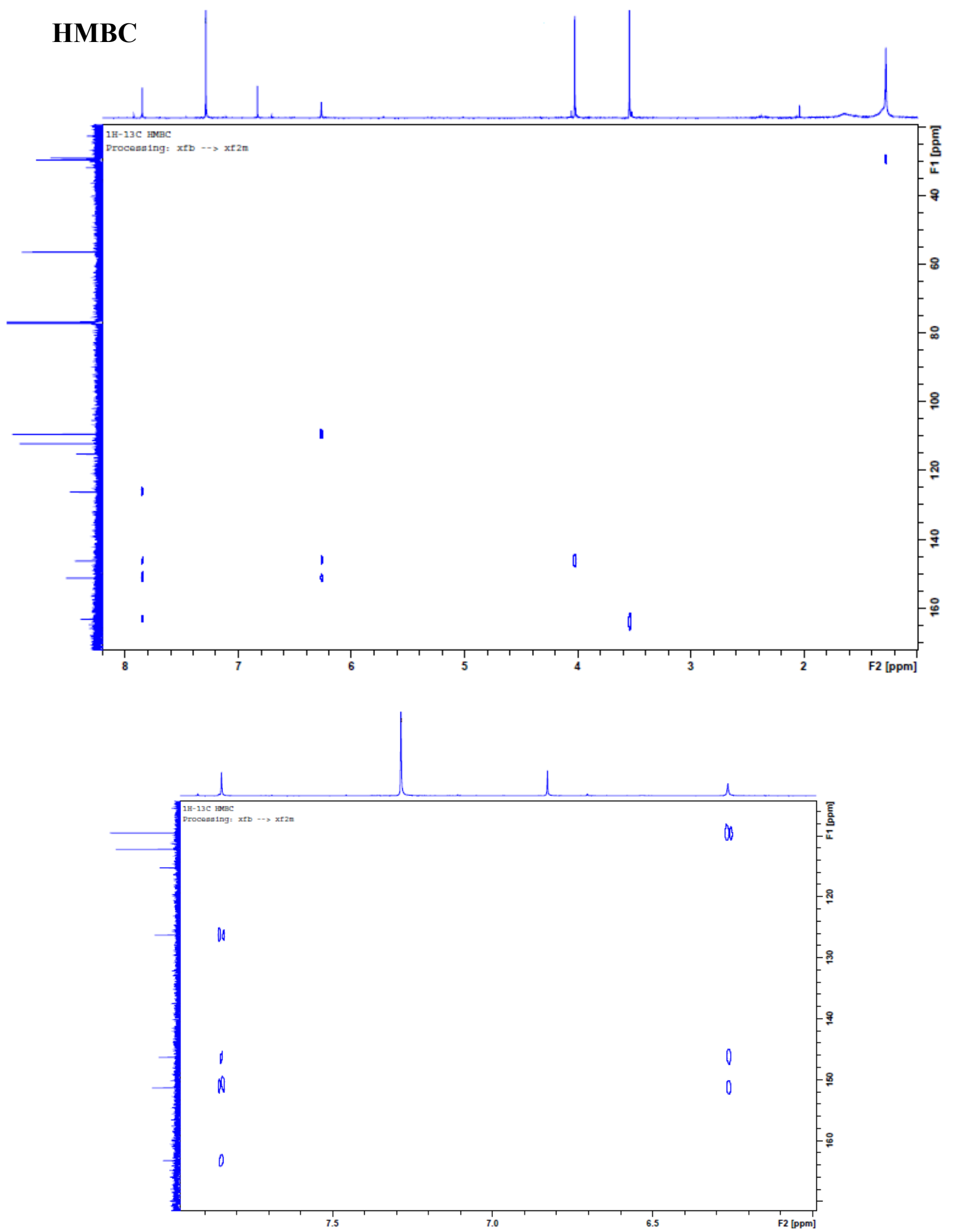




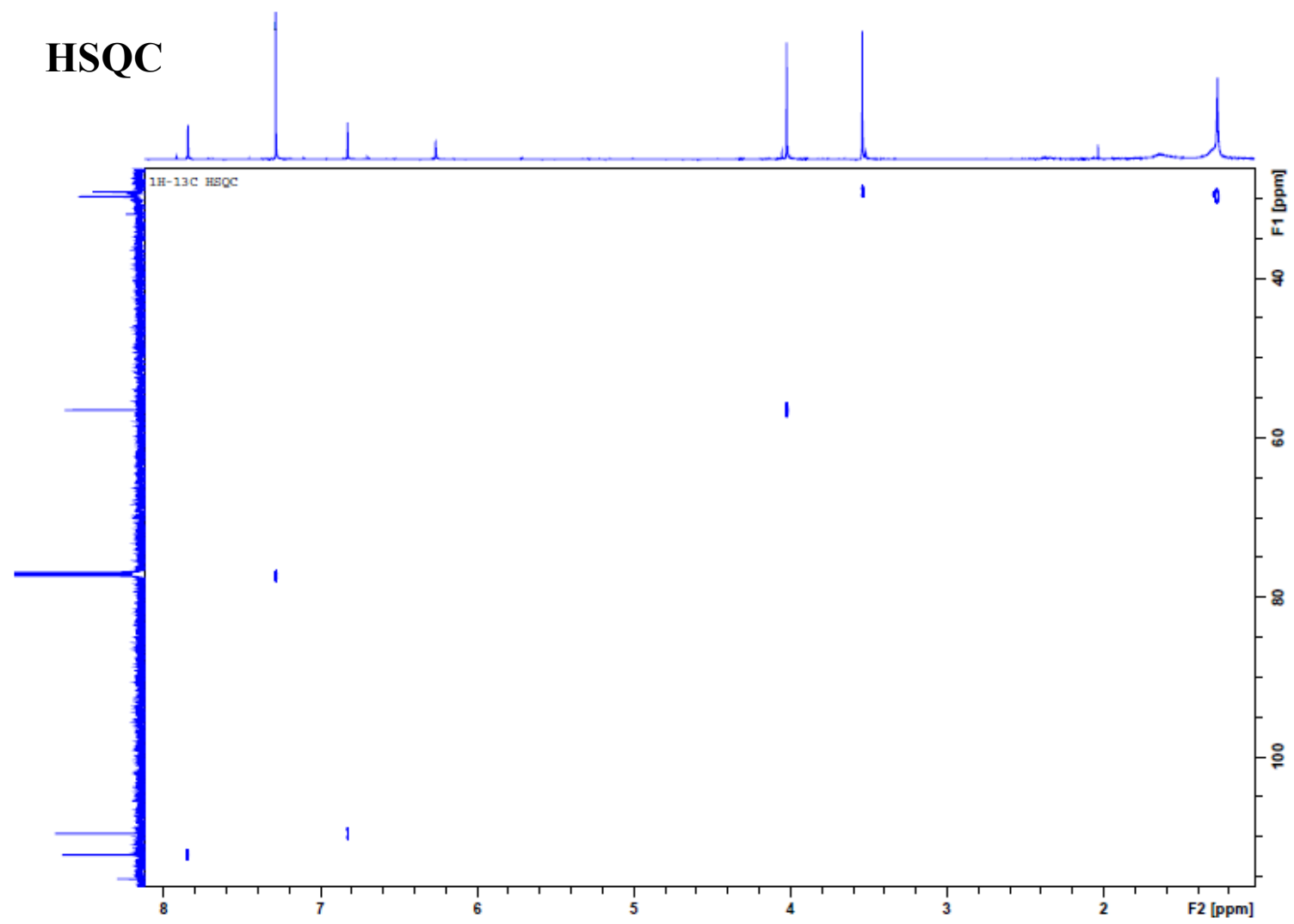




\section{NOEs}

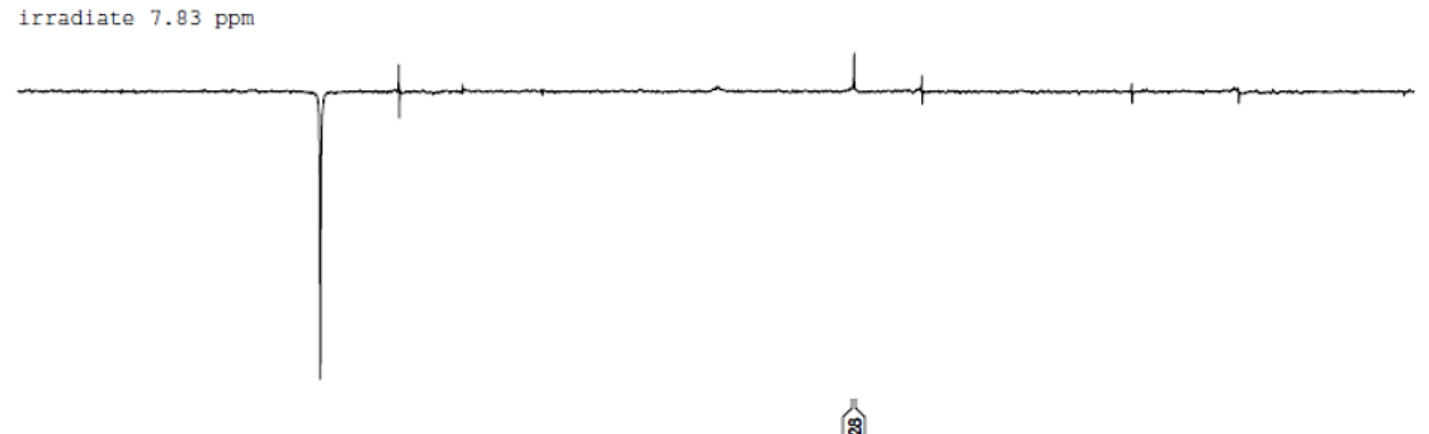

శ్ำ

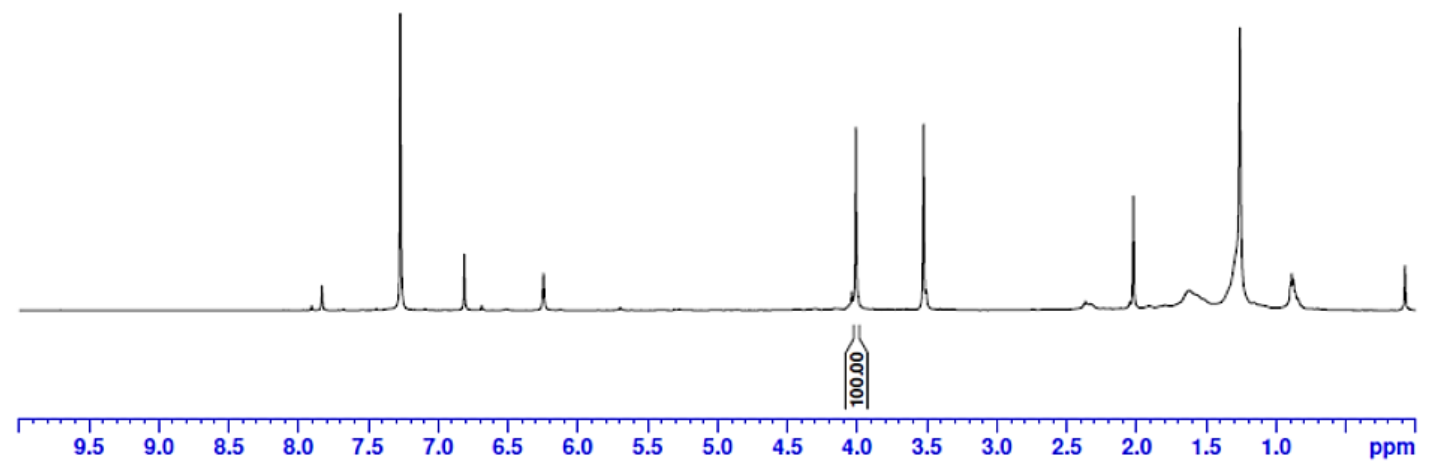

irradiate $4.01 \mathrm{ppm}$

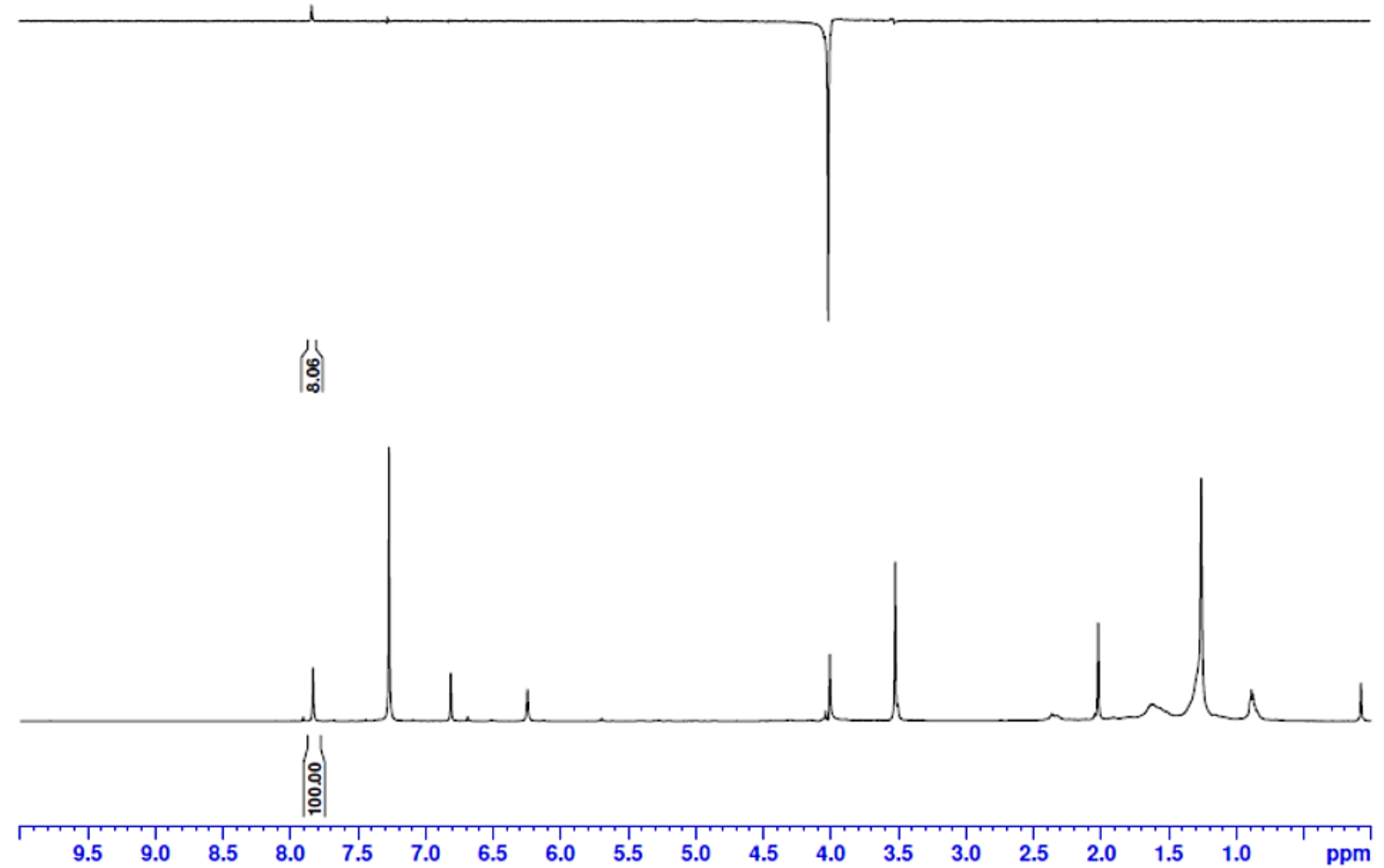




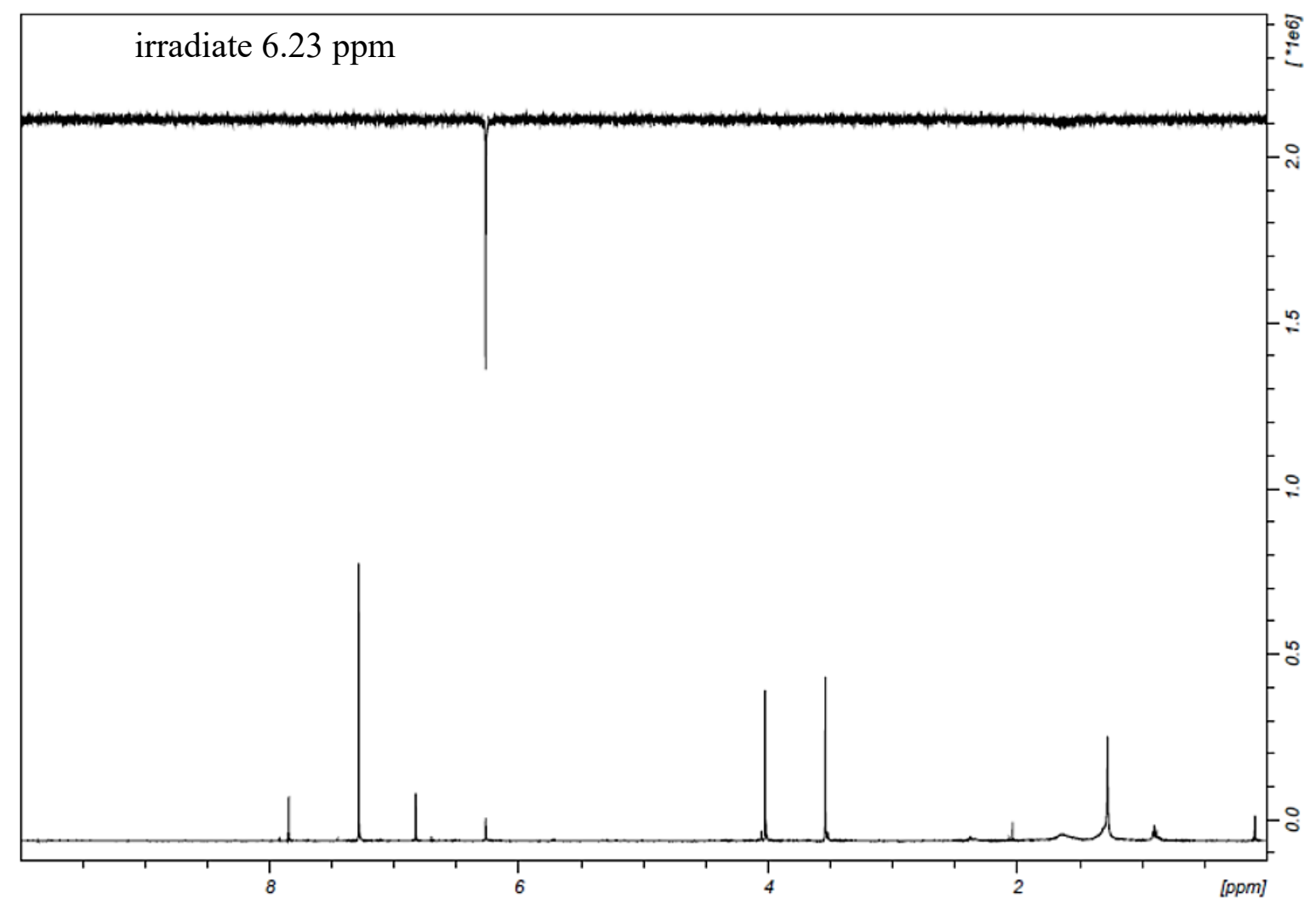

